\title{
27. COLOR BANDS IN ONTONG JAVA PLATEAU CARBONATE OOZES AND CHALKS ${ }^{1}$
}

\author{
Ida L. Lind, ${ }^{2}$ Thomas R. Janecek, ${ }^{3}$ Lawrence A. Krissek, ${ }^{4}$ Michael L. Prentice, ${ }^{5}$ \\ and Rainer Stax ${ }^{6}$
}

\begin{abstract}
Light greenish gray and pale purple color bands are common in the ooze and chalk of the Ontong Java Plateau. Analyses of Pleistocene and Pliocene ooze samples that contain abundant bands indicate that the purple bands are colored by finely disseminated iron sulfide, whereas the green bands are colored by finely disseminated $\mathrm{Fe}$ - and $\mathrm{Al}$-bearing silicates (probably clays). No local contrasts in the total organic carbon contents, carbon and oxygen isotopic compositions, and grain sizes were found.

Band abundances, counted from core photographs of all Leg 130 holes, can be correlated from hole to hole on the basis of age rather than depth. The temporal distribution of these color bands is also comparable with that of the green bands described from the Lord Howe Rise, which were previously interpreted as products of altered volcanic glass. This may indicate that the green and purple bands on the Ontong Java Plateau originate from the early alteration of volcanic ash.

The crosscutting relationships between the green and purple bands and original structures in the host sediment indicate that the bands have been locally altered by redox conditions in the sediments after the bands were formed.
\end{abstract}

\section{INTRODUCTION}

Numerous color bands are present in the Pleistocene to Oligocene ooze and chalk recovered from the Ontong Java Plateau during Ocean Drilling Program (ODP) Leg 130. Color bands were noted previously in cores from the Ontong Java Plateau (Winterer, Riedel, et al., 1971; Andrews, Packham, et al., 1975; Kennett, von der Borch, et al., 1986) and also were found in calcareous sediments from the Rio Grande Rise (Supko, Perch-Nielsen, et al., 1977) and the Lord Howe Rise (Kennett, von der Borch, et al., 1986). The color bands on the Lord Howe Rise were described in some detail by Gardner et al. (1986). The bands and laminae on the Lord Howe Rise are green in color and commonly are associated with iron sulfide sockets. The laminae, which are found in sediments of Oligocene to Pleistocene age, are thin $(<2 \mathrm{~mm}$ thick) and are only faintly colored.

Gardner et al. (1986) proposed a volcanic origin for the laminae on the Lord Howe Rise, based on the following observations: (1) the temporal distribution of the laminae is similar to the distribution of volcanic ash layers elsewhere in the southwest Pacific, (2) a high abundance of authigenic smectite was found in the clay fraction, and (3) iron sulfides are common in the proximity of most of the laminae.

Formation of the color bands on the Lord Howe Rise by cyclic sedimentation was ruled out by Gardner et al. (1986) because (1) individual laminae are $<2 \mathrm{~mm}$ thick whereas the surrounding unlaminated facies is more than $50 \mathrm{~cm}$ thick, and (2) the calcareous microfossils and grain sizes of the laminae and adjacent sediments are similar. An origin resulting from cyclic diagenesis was also ruled out because the entire section below $1-2 \mathrm{~m}$ below seafloor (mbsf) is anoxic and mildly sulfate reducing, as demonstrated by the presence of iron sulfides.

Although the color bands are a common and conspicuous feature in sediments recovered during Leg 130 , the origin and potential sig-

${ }^{1}$ Berger, W.H., Kroenke, L.W., Mayer, L.A., et al., 1993. Proc. ODP, Sci. Results, 130: College Station, TX (Ocean Drilling Program).

${ }^{2}$ Instituttet for Geologi og Geoteknik, Danmarks Tekniske Højskole, Bygning 204. DK-2800 Lyngby, Denmark.

${ }^{3}$ Ocean Drilling Program, Texas A\&M University, 1000 Discovery Drive, College Station, TX 77845-9547, U.S.A.

${ }^{4}$ Department of Geology and Mineralogy, Ohio State University, 125 South Oval Mall, Columbus, OH 43210-1298, U.S.A.

${ }^{5}$ Department of Geological Sciences, University of Maine, 111 Boardman Hall. Orono, ME 04469, U.S.A.

${ }^{6}$ Alfred Wegener Institute for Polar and Marine Research, Columbusstrasse, D-2850 Bremerhaven, Federal Republic of Germany. nificance of the color bands are not obvious from shipboard observations. The explanation advanced by Gardner et al. (1986) for the origin of green laminae in sediments of the Lord Howe Rise was largely based on circumstantial evidence, and the validity of such an explanation has not been explicitly tested in other geographic areas. In fact, shipboard observations during Leg 130 suggest that the color bands on the Ontong Java Plateau have a complex multistage origin, at least partially controlled by diagenetic reactions. This complexity is indicated by observations of color bands that are continuous across biogenic structures, but that change color across the biogenic structures. As a result, this study was designed to answer three major questions:

1. What is the physical/chemical source of the color in these bands? This question was investigated by defining chemical differences between the color bands and the host material, and by comparing the noncarbonate mineralogy of the color bands with that of the surrounding sediments.

2. What external factors influence the development of the minerals responsible for the coloration? Do any such effects mean that the distribution of color bands records cyclic variations in climate, productivity, dissolution, and so forth? This question was addressed by examining geographic and stratigraphic associations between the Ontong Java Plateau color bands and sedimentary proxies for environmental variables such as productivity (organic carbon contents, carbon isotopes, relative abundance of microfossils as reflected in sediment grain size), global climate (oxygen isotopes), and the general supply of volcanic ash (data from Gardner et al., 1986).

3. What internal factors control the presence of the chemical phases responsible for the coloration? This question was addressed by considering the distribution of the color bands relative to porewater data, the stability of the chemical phases during redox reactions, and the physical characteristics of the color bands relative to smallscale sedimentary features, such as burrows and burrow-related redox boundaries.

This project has successfully identified the chemical sources of the coloration and has demonstrated that the origin of such phases is not directly tied to cyclic variations in global climate, surfacewater productivity, or dissolution. Instead, color bands on Ontong Java Plateau appear to develop as minor concentrations of volcanic ash are transformed through one or several stages of diagenesis; the specific conditions that drive the diagenetic reactions remain unknown, however. 


\section{GENERAL DESCRIPTION}

The bands are colored in shades of green and purple, vary in thickness from $<1 \mathrm{~mm}$ to $>1 \mathrm{~cm}$ and are observed from a few meters below the seafloor to a sub-bottom depth of about $1 \mathrm{~km}$. As a result, the color bands are distributed through sediments of Oligocene to Pleistocene age. The colors are generally more intense in sediments from the deeper water sites ( 803 and 804 ) than the shallower sites $(805,806$, and 807$)$, and the bands become thinner and more intense with increasing depth in each hole. Bands in the upper few hundred meters sub-bottom are broad and diffuse (Plate 1, Fig. 1), whereas those at greater depths (Plate 2, Fig. 2) are distinct and generally thinner than $1 \mathrm{~mm}$. The distinct bands commonly occur either in zones with multiple bands or as single bands within faintly colored intervals several centimeters thick.

The greenish bands are generally horizontal and of constant thickness; the purplish bands also occur as well-defined horizontal bands, but commonly are difficult to distinguish from purplish haloes and streaks associated with burrows. The color bands also may form pairs of a greenish and a purplish band, but no preferred sequence (purple over green vs. green over purple) was evident. Relationships between the color bands and other sedimentary structures are shown in Plate 2 and suggest the diagenetic nature of the bands. Color bands crosscut burrows and thus postdate bioturbation (Plate 2, Fig. 1). Color bands also change color across burrow-induced redox fronts, from greenish inside a purple halo to purplish outside (Plate 2, Fig. 2).

\section{METHODOLOGY}

\section{Sampling}

The Pleistocene and Pliocene sediments of Hole 807B were chosen for detailed chemical and lithologic analyses of the color bands, to maximize preservation of the sedimentary signals and to minimize difficulties in their interpretation. Eight intervals containing greenish gray bands or greenish gray and pale purple bands were sampled. The eight intervals are lettered $\mathrm{A}$ through $\mathrm{H}$, where $\mathrm{A}$ is the shallowest interval, $\mathrm{H}$ the deepest. Each band, as well as the host sediment directly over- and underlying it, was sampled in triplicate. One sample set was collected in $10-\mathrm{cm}^{3}$ containers, the second was collected in $2-\mathrm{cm}^{3}$ containers, and the third was collected in $6-\mathrm{cm}^{3}$ plastic paleomagnetic cubes to ensure that sedimentary structures were preserved.

The $10-\mathrm{cm}^{3}$ sample set was analyzed for carbon and oxygen isotopes and the mineralogy of the insoluble residues. The $2-\mathrm{cm}^{3} \mathrm{set}$ was used for grain-size analysis, and the $6-\mathrm{cm}^{3}$ samples were used for petrography, backscatter electron microscopy (BSE), microprobe (EDS) analysis, atomic absorption (AAS) analysis, and total organic carbon (TOC) and carbonate carbon analyses.

\section{Atomic Absorption Analysis}

One gram of sample was dried at $105^{\circ} \mathrm{C}$ and weighed. The sample was treated with phosphoric acid and autoclaved at $2 \mathrm{br}$ and $120^{\circ} \mathrm{C}$. The filtrate was analyzed by $\mathrm{AAS}$ for $\mathrm{Ca}, \mathrm{Mg}, \mathrm{Fe}, \mathrm{Mn}, \mathrm{Al}, \mathrm{Na}$, and $\mathrm{K}$. Standard deviations on element concentrations based on analyses of duplicate samples are: $\mathrm{Ca}=0.2 \%-1.0 \%, \mathrm{Mg}=0.00 \%-0.02 \%, \mathrm{Fe}=$ $0.01 \%-0.2 \%, \mathrm{Mn}=0.001 \%-0.002 \%, \mathrm{Al}=0.00 \%-0.03 \%, \mathrm{Na}=$ $0.00 \%-0.09 \%$, and $\mathrm{K}=0.000 \%-0.006 \%$. The residues of the four samples from Interval $\mathrm{F}$ were dissolved in aqua regia and hydrofluoric acid, and subsequently analyzed by AAS. The total compositions of the samples that were completely dissolved were not significantly different from the compositions determined on the basis of treatment with phosphoric acid alone. (The residues from Interval $\mathrm{F}$ contained $85 \%-100 \% \mathrm{SiO}_{2}$ and $<0.2 \% \mathrm{Al}_{2} \mathrm{O}_{3}$ ).

\section{Total Organic Carbon and Carbonate Contents}

The TOC and carbonate contents were measured on 1-g samples. Each sample was dried and ground and $30 \mathrm{mg}$ was weighed for analysis. The measurements were made using a Heraeus $\mathrm{CHN}$ analyzer. The CHN analyzer has an accuracy of $0.02 \%$ and standard deviation of $0.2 \%$.

\section{Mineralogical Analysis}

Mineralogy was analyzed by X-ray diffractometry of pressed powdered mounts of bulk samples, as well as by the analysis of sample residues after treatment with cold $20 \% \mathrm{HCl}$. Scans were performed using $\mathrm{Cu}-\mathrm{K} \alpha$ radiation at machine settings of $15 \mathrm{~mA}$ and $35 \mathrm{kV}$.

\section{Petrography}

After sampling for AAS and TOC analyses, the $6-\mathrm{cm}^{3}$ samples were dried at $50^{\circ} \mathrm{C}$, impregnated with epoxy, and polished. The samples were imaged by BSE, and two samples were chosen for elemental analysis using the microprobe. The Jeol 733/Super Probe at the Geological Institute, University of Copenhagen, was used.

\section{Microprobe Analyses}

Carbon-coated samples were scanned over areas of $1.5 \times 1.2 \mathrm{~mm}$. This abnormally large area was necessary to achieve representative values for this microfossil-rich sediment. The following elements were selected from the EDS spectrum: $\mathrm{Ca}$ (calcite standard), $\mathrm{Mg}$ (Mg-rich olivine standard), $\mathrm{Fe}$ (hematite standard), $\mathrm{Al}$ (corundum standard), K (K-feldspar standard), S (barite standard), and Si (wollastonite standard). $\mathrm{Ti}$ and $\mathrm{Mn}$ were also selected, but the number of counts for Mn and $\mathrm{Ti}$ was generally lower than the statistical counting error. Carbonate was accounted for in the matrix correction by assigning 3 oxygen to each $\mathrm{Ca}$. An acceleration voltage of $15 \mathrm{kV}$ and a reference current of $5.01 \mathrm{nA}$ were used. The EDS detector was used with a take-off angle of $40^{\circ}$ and 100 -s counting time. For Fe, K, and $\mathrm{Mg}$, the counts were roughly the same magnitude as the counting error. For Al, the counts were generally twice the statistical error, whereas the counts for $\mathrm{Ca}, \mathrm{Si}$, and $\mathrm{S}$ were at least 1 order of magnitude larger than the statistical error. The areas analyzed were aligned in profiles either parallel to or normal to the color bands. To confirm the origin of the green color, secondary X-ray dot-pictures were taken over small selected areas at large magnification.

\section{Grain-size Analyses}

Grain-size analyses were conducted on raw sample splits using a Laser Sensor Technology Lab-Tec 100ME particle-size analyzer. A sample was prepared for analysis by first dispersing about $1 \mathrm{~cm}^{3}$ of the sample in a $4 \%$ (by weight) Calgon solution. The sample was then shaken gently for $15 \mathrm{~min}$ in a wrist-action shaker, after which the sample was poured into an optically smooth beaker for analysis by the Lab-Tec $100 \mathrm{ME}$ analyzer. The analysis of replicate samples indicates a reproducibility of $\pm 1 \mu \mathrm{m}$.

\section{Oxygen and Carbon Isotope Analysis}

Specimens of the planktonic foraminifer Globigerinoides trilobus were ultrasonically cleaned in ethanol, loaded and crushed in boats, and then roasted in a vacuum at $370^{\circ} \mathrm{C}$ for $1 \mathrm{hr}$. Samples were then reacted with $100 \%$ orthophosphoric acid at $90^{\circ} \mathrm{C}$. The resulting $\mathrm{CO}_{2}$ was analyzed in an on-line, fully automated VG-Sira-24 mass spectrometer at the Benedum Stable Isotope Laboratory of Brown University. Analytical precision, based on carbonate standards bracketing each sample batch for the duration of the project, is $0.1 \%$ and $0.08 \%$ (standard deviation) for oxygen and carbon, respectively. Precision based on 21 replicated samples of G. trilobus is $0.1 \%$ and $0.1 \%$ (standard deviation) for oxygen and carbon, respectively. All data are reported in standard notation relative to PDB using the Craig calibration and specific isotope correction equations (Craig, 1957). 


\section{Spatial and Temporal Abundance}

The distribution of color bands was recorded on a core-by-core basis as the number of bands per well-preserved meter of sediment. The bands were counted from core photographs for all holes; for Holes $806 \mathrm{~B}, 806 \mathrm{C}, 807 \mathrm{~A}, 807 \mathrm{~B}$, and $807 \mathrm{C}$ they were also counted directly from the split surface during shipboard core description. Because some bands are faint, some are present in densely spaced groups, and some purple bands are difficult to distinguish from burrow-related halos, the bands were counted twice. One count identified every potential color band, and serves as a maximum estimate of color band abundance, whereas the second count included only clearly defined bands and serves as a minimum estimate of color band abundance. Downcore ages were calculated from sedimentation rates given in Kroenke, Berger, Janecek, et al. (1991).

\section{RESULTS}

\section{Characterization of the Color Bands}

\section{Bulk Inorganic Geochemistry}

The AAS results are listed in Table 1 and show only small variations in composition between green bands, purple bands, and the host sediment. The concentrations of $\mathrm{Mg}$ and $\mathrm{Fe}$ are plotted in
Figure 1. These data indicate that a relatively high content of $\mathrm{Mg}$ may be attributed to the presence of a green band, whereas a relatively high content of Fe may be attributed to the presence of a green or a purple band. For most intervals, however, the differences between the composition of bands and the surrounding white ooze are low. Average $\mathrm{Fe}$ and $\mathrm{Mg}$ contents in the samples are listed in Table 1. Because the color band bearing samples analyzed include both color bands and background ooze, these averages are not the exact content of $\mathrm{Fe}$ and $\mathrm{Mg}$ in the bands themselves.

\section{Mineralogy}

The X-ray diffractograms of bulk samples are dominated by calcite, with trace amounts of other components present in some samples. The apparent distribution of the other components does not correlate well with sediment color, however. For example, approximately $70 \%$ of the white samples contains only calcite and the remainder contains calcite with a trace of expandable clays. Approximately $30 \%$ of the light greenish gray bands contains only calcite, and approximately $70 \%$ contains calcite and trace amounts of assorted clays ( $10 \AA, 14 \AA$, and expandables). Approximately $50 \%$ of the pale purple samples contains only calcite, approximately $35 \%$ contains calcite and traces of assorted clays (14 $\AA$ and expandables), and $15 \%$ contains calcite with perhaps a trace of pyrite.

Table 1. Atomic absorption (AAS) analysis results, Hole 807B.

\begin{tabular}{|c|c|c|c|c|c|c|c|c|c|c|c|c|c|c|c|c|c|c|c|}
\hline Interval & $\begin{array}{l}\text { Core, section, } \\
\text { interval }(\mathrm{cm})\end{array}$ & w & d & $\begin{array}{l}\text { Insoluble } \\
\text { residue } \\
(\%)\end{array}$ & $\begin{array}{l}\mathrm{Ca} \\
(\%)\end{array}$ & $\begin{array}{l}\mathrm{Mg} \\
(\%)\end{array}$ & $\begin{array}{l}\mathrm{Na} \\
(\%)\end{array}$ & $\begin{array}{c}\mathrm{K} \\
(\%)\end{array}$ & $\begin{array}{l}\mathrm{Fe} \\
(\%)\end{array}$ & $\begin{array}{l}\mathrm{Mn} \\
(\%)\end{array}$ & $\begin{array}{c}\mathrm{Al} \\
(\%)\end{array}$ & $\begin{array}{l}\text { Sum of } \\
\text { analyzed } \\
\text { elements } \\
(\%)\end{array}$ & $\begin{array}{c}\mathrm{CO}_{3}, \\
\mathrm{Ca} \\
(\%)\end{array}$ & $\begin{array}{l}\mathrm{CO}_{3}, \\
\mathrm{Mg} \\
(\%)\end{array}$ & $\begin{array}{c}\mathrm{O}, \\
\mathrm{Na}+\mathrm{K} \\
(\%)\end{array}$ & $\begin{array}{l}\mathrm{S}, \\
\mathrm{Fe} \\
(\%)\end{array}$ & $\begin{array}{l}\mathrm{CO}_{3}, \\
\mathrm{Mn} \\
(\%)\end{array}$ & $\begin{array}{c}\mathrm{O}, \\
\mathrm{Al} \\
(\%)\end{array}$ & $\begin{array}{l}\text { Total } \\
\text { sum } \\
(\%)\end{array}$ \\
\hline A & $2 \mathrm{H}-4,92-93$ & & & 3.63 & 35.3 & 0.32 & 0.98 & 0.15 & 0.48 & 0.04 & 0.51 & 41.4 & 52.9 & 0.79 & 0.37 & 0.55 & 0.04 & 0.45 & 96.5 \\
\hline A & $2 \mathrm{H}-4,94-96$ & $\mathrm{~g}$ & $\mathrm{~g}$ & 3.82 & 34.5 & 0.31 & 0.93 & 0.15 & 0.48 & 0.04 & 0.49 & 40.7 & 51.7 & 0.77 & 0.35 & 0.55 & 0.04 & 0.44 & 94.5 \\
\hline A & $2 \mathrm{H}-4,97-99$ & & & 3.06 & 35.4 & 0.28 & 0.94 & 0.13 & 0.35 & 0.04 & 0.42 & 40.6 & 53.0 & 0.69 & 0.35 & 0.40 & 0.04 & 0.37 & 95.5 \\
\hline B & $2 \mathrm{H}-5,30-32$ & & $\mathrm{~g}$ & 3.81 & 35.3 & 0.32 & 0.96 & 0.16 & 0.43 & 0.04 & 0.55 & 41.6 & 52.9 & 0.79 & 0.37 & 0.49 & 0.04 & 0.49 & 96.6 \\
\hline B & $2 \mathrm{H}-5,36-38$ & $\mathrm{~g}$ & & 3.19 & 35.4 & 0.34 & 0.94 & 0.16 & 0.55 & 0.04 & 0.49 & 41.1 & 53.0 & 0.84 & 0.36 & 0.63 & 0.04 & 0.44 & 96.4 \\
\hline B & $2 \mathrm{H}-5,42-44$ & & & 2.45 & 35.4 & 0.28 & 0.93 & 0.14 & 0.33 & 0.04 & 0.46 & 40.0 & 53.0 & 0.69 & 0.35 & 0.38 & 0.04 & 0.41 & 94.9 \\
\hline C & $2 \mathrm{H}-5,119-121$ & & & 3.29 & 35.2 & 0.31 & 0.97 & 0.14 & 0.42 & 0.04 & 0.45 & 40.8 & 52.7 & 0.77 & 0.37 & 0.48 & 0.04 & 0.40 & 95.6 \\
\hline $\mathrm{C}$ & $2 \mathrm{H}-5,122-124$ & b & & 2.35 & 36.1 & 0.31 & 1.02 & 0.13 & 0.41 & 0.04 & 0.42 & 40.8 & 54.1 & 0.77 & 0.38 & 0.47 & 0.04 & 0.37 & 96.9 \\
\hline $\mathrm{C}$ & $2 \mathrm{H}-5,124-126$ & $\mathrm{~g}$ & $\mathrm{~g}$ & 3.56 & 34.5 & 0.39 & 1.00 & 0.18 & 0.86 & 0.03 & 0.46 & 41.0 & 51.7 & 0.96 & 0.38 & 0.99 & 0.04 & 0.41 & 95.4 \\
\hline C & $2 \mathrm{H}-5,128-130$ & & & 2.47 & 35.6 & 0.30 & 0.98 & 0.13 & 0.33 & 0.04 & 0.46 & 40.3 & 53.3 & 0.74 & 0.37 & 0.38 & 0.04 & 0.41 & 95.5 \\
\hline D & $2 \mathrm{H}-6,55-57$ & & b & 2.83 & 35.7 & 0.31 & 1.04 & 0.15 & 0.37 & 0.03 & 0.51 & 40.9 & 53.5 & 0.77 & 0.39 & 0.42 & 0.03 & 0.45 & 96.5 \\
\hline D & $2 \mathrm{H}-6,59-61$ & b & & 2.94 & 35.3 & 0.31 & 0.99 & 0.16 & 0.41 & 0.04 & 0.56 & 40.7 & 52.9 & 0.77 & 0.38 & 0.47 & 0.04 & 0.50 & 95.7 \\
\hline D & $2 \mathrm{H}-6,62-64$ & & & 2.89 & 35.3 & 0.30 & 0.97 & 0.15 & 0.40 & 0.04 & 0.50 & 40.5 & 52.9 & 0.74 & 0.37 & 0.46 & 0.04 & 0.44 & 95.5 \\
\hline E & $4 \mathrm{H}-6,27-29$ & & & 3.72 & 35.5 & 0.34 & 0.99 & 0.14 & 0.38 & 0.03 & 0.50 & 41.6 & 53.2 & 0.84 & 0.37 & 0.44 & 0.03 & 0.44 & 96.9 \\
\hline E & $4 \mathrm{H}-6,30-32$ & $g$ & g & 3.73 & 38.0 & 0.37 & 1.01 & 0.15 & 0.50 & 0.03 & 0.51 & 44.3 & 56.9 & 0.91 & 0.38 & 0.57 & 0.03 & 0.45 & 104.0 \\
\hline E & $4 \mathrm{H}-6,33-35$ & $\mathrm{~b}$ & & 3.70 & 36.2 & 0.33 & 1.03 & 0.14 & 0.36 & 0.03 & 0.46 & 42.3 & 54.3 & 0.81 & 0.39 & 0.41 & 0.03 & 0.43 & 98.5 \\
\hline $\mathrm{E}$ & $4 \mathrm{H}-6,40-42$ & & & 2.80 & 35.2 & 0.33 & 1.00 & 0.14 & 0.35 & 0.03 & 0.49 & 40.3 & 52.7 & 0.81 & 0.38 & 0.40 & 0.03 & 0.44 & 95.1 \\
\hline $\mathrm{F}$ & $4 \mathrm{H}-6,115-117$ & & $\mathrm{~g}$ & 3.08 & 35.3 & 0.31 & 0.97 & 0.16 & 0.32 & 0.03 & 0.38 & 40.5 & 52.9 & 0.77 & 0.37 & 0.37 & 0.03 & 0.34 & 95.3 \\
\hline $\mathrm{F}$ & $4 \mathrm{H}-6,119-121$ & $\mathrm{~g}$ & $\mathrm{~b}$ & 2.67 & 34.7 & 0.37 & 1.06 & 0.14 & 0.52 & 0.03 & 0.43 & 39.9 & 52.0 & 0.91 & 0.40 & 0.60 & 0.03 & 0.38 & 94.2 \\
\hline $\mathrm{F}$ & $4 \mathrm{H}-6,122-124$ & b & b & 2.40 & 33.0 & 0.30 & 0.91 & 0.12 & 3.45 & 0.03 & 0.37 & 40.6 & 49.4 & 0.74 & 0.34 & 3.96 & 0.03 & 0.33 & 95.4 \\
\hline $\mathrm{F}$ & $4 \mathrm{H}-6,131-133$ & & & 2.54 & 34.9 & 0.33 & 0.97 & 0.13 & 0.32 & 0.03 & 0.45 & 39.7 & 52.3 & 0.81 & 0.36 & 0.37 & 0.03 & 0.40 & 93.9 \\
\hline G & $5 \mathrm{H}-1,92-94$ & $g$ & g & 3.27 & 34.7 & 0.35 & 0.94 & 0.15 & 0.47 & 0.02 & 0.47 & 40.4 & 52.0 & 0.86 & 0.36 & 0.54 & 0.03 & 0.42 & 94.5 \\
\hline G & $5 \mathrm{H}-1,95-97$ & $\mathrm{~b}$ & b & 3.89 & 36.8 & 0.30 & 0.89 & 0.14 & 0.34 & 0.02 & 0.49 & 42.9 & 55.1 & 0.74 & 0.34 & 0.39 & 0.02 & 0.44 & 99.9 \\
\hline G & $5 \mathrm{H}-1,98-100$ & & & 3.71 & 34.6 & 0.31 & 0.92 & 0.15 & 0.34 & 0.02 & 0.54 & 40.6 & 51.8 & 0.77 & 0.35 & 0.39 & 0.02 & 0.48 & 94.4 \\
\hline $\mathrm{H}$ & $5 \mathrm{H}-5,5-7$ & & & 3.03 & 35.3 & 0.28 & 0.92 & 0.12 & 0.23 & 0.02 & 0.39 & 40.3 & 52.9 & 0.69 & 0.35 & 0.26 & 0.03 & 0.35 & 94.8 \\
\hline $\mathrm{H}$ & $5 \mathrm{H}-5,8-10$ & $b$ & & 2.68 & 35.0 & 0.32 & 0.92 & 0.13 & 0.44 & 0.02 & 0.39 & 39.9 & 52.4 & 0.79 & 0.35 & 0.51 & 0.02 & 0.35 & 94.3 \\
\hline $\mathrm{H}$ & $5 \mathrm{H}-5,11-13$ & $\mathrm{~g}$ & $\mathrm{~g}$ & 2.79 & 35.3 & 0.31 & 0.91 & 0.13 & 0.40 & 0.02 & 0.40 & 40.3 & 52.9 & 0.77 & 0.34 & 0.46 & 0.02 & 0.36 & 95.1 \\
\hline \multirow[t]{6}{*}{$\mathrm{H}$} & $5 \mathrm{H}-5,14-16$ & & & 1.62 & 35.7 & 0.28 & 0.83 & 0.11 & 0.25 & 0.02 & 0.34 & 39.2 & 53.5 & 0.69 & 0.31 & 0.29 & 0.02 & 0.30 & 94.2 \\
\hline & Average, white & & & 2.93 & 35.3 & 0.31 & 0.95 & 0.13 & 0.36 & 0.03 & 0.46 & 40.4 & 52.8 & 0.75 & 0.36 & 0.40 & 0.03 & 0.41 & 95.2 \\
\hline & Average, green & $\mathrm{g}$ & $\mathrm{g}$ & 3.43 & 35.4 & 0.35 & 0.96 & 0.15 & 0.54 & 0.03 & 0.47 & 41.3 & 53.0 & 0.85 & 0.36 & 0.62 & 0.03 & 0.41 & 96.6 \\
\hline & Average, green & & $\mathrm{g}$ & 3.45 & 35.3 & 0.32 & 0.97 & 0.16 & 0.38 & 0.04 & 0.47 & 41.1 & 52.9 & 0.78 & 0.37 & 0.43 & 0.04 & 0.41 & 95.9 \\
\hline & Average, blue & b & $b$ & 3.15 & 34.9 & 0.30 & 0.90 & 0.13 & 1.90 & 0.02 & 0.43 & 41.7 & 52.3 & 0.74 & 0.34 & 2.18 & 0.03 & 0.38 & 97.6 \\
\hline & Average, blue & b & & 2.92 & 35.7 & 0.32 & 0.99 & 0.14 & 0.41 & 0.03 & 0.46 & 40.9 & 53.4 & 0.78 & 0.37 & 0.46 & 0.03 & 0.41 & 96.4 \\
\hline
\end{tabular}

Notes: $\mathrm{g}=$ samples with green bands, $\mathrm{b}=$ samples with purple (blue) bands as observed on wet surface ( $w$ ) during initial sampling and on the dry, epoxy-impregnated, polished surface (d). Anion concentrations on the right-hand side are calculated from cation values. 

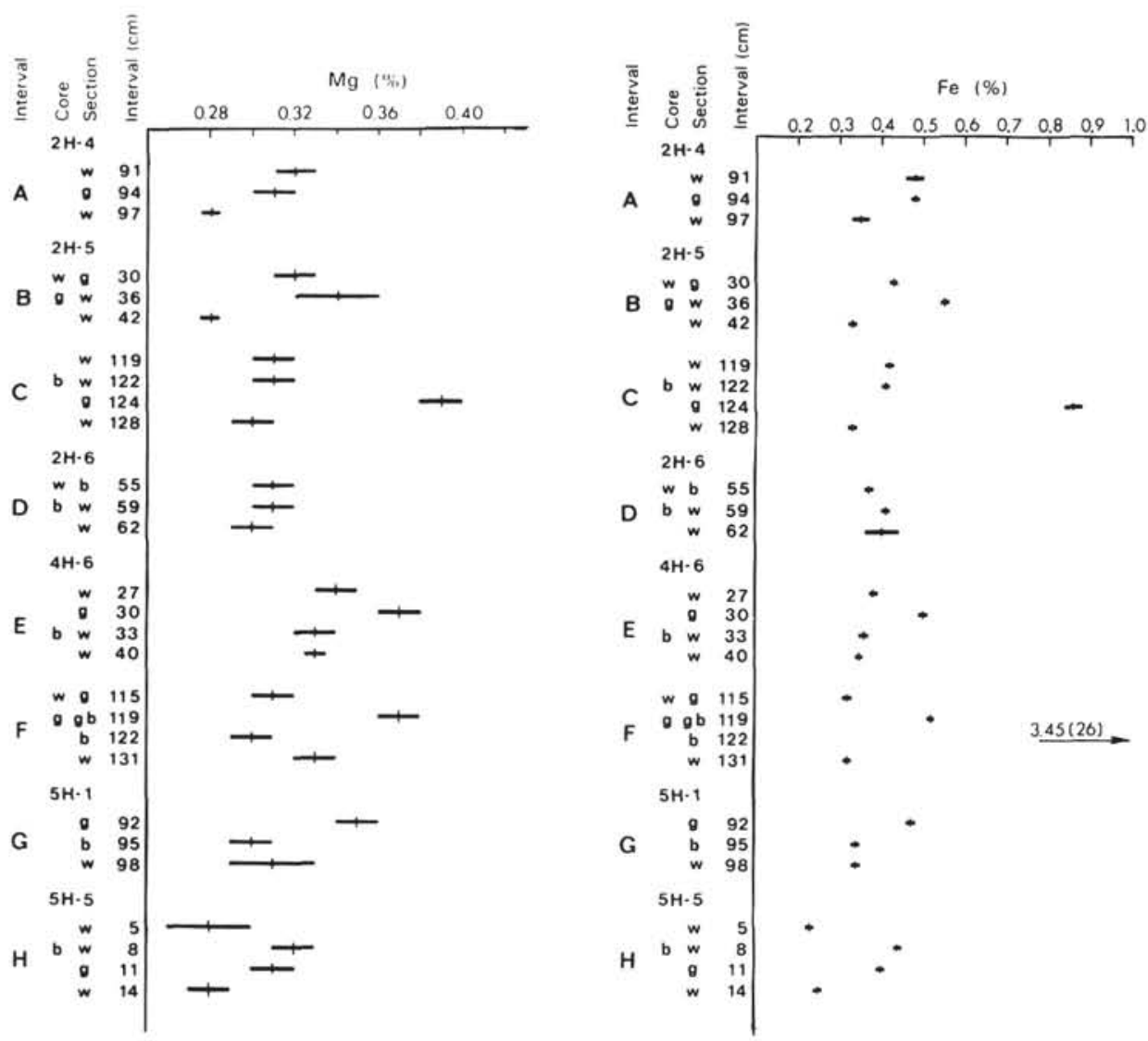

Figure 1. Mg and Fe concentrations in bulk samples from atomic absorption (AAS) analyses, Hole 807B. Sample codes given in Table 1. Average values are marked as data points, whereas the bar indicates \pm 1 standard deviation.

Treatment with cold $20 \% \mathrm{HCl}$ left small amounts of residue, and no diffracting phases could be detected in the residues by X-ray diffraction (XRD) analysis.

\section{Petrography}

The color bands, which had disappeared during drying, generally reappeared after epoxy impregnation and polishing, but the colors were less intense. The positions and colors visible on the wet surface during initial description and sampling do not always correlate with the color bands that appear on the dry surface after impregnation (Table 1). These differences are most marked for the pale purple bands.

BSE microscopy points unequivocally to the presence of finely disseminated authigenic iron sulfide in the purple bands (Plate 3). No source for the green bands was evident from BSE.

\section{High-resolution Geochemistry}

Microprobe scans (Figs. 2 and 3) support the interpretation of the purple bands as caused by iron sulfide (high content of $\mathrm{Fe}$ and $\mathrm{S}$ in a ratio suitable for pyrite or marcasite), whereas the green bands are relatively rich in $\mathrm{Fe}, \mathrm{Mg}$, and $\mathrm{Si}$.

To define the source of the green color, secondary X-ray dot pictures were recorded over a green band, first at low magnification ( $100 \times$, corresponding to $1.5 \times 1.2 \mathrm{~mm}$ ), where the most Fe-rich areas were identified, and then at progressively higher magnifications until lumps of silicates $10-20 \mu \mathrm{m}$ in size were detected (Plates 4 and $5)$. The dot pictures indicate a homogeneous chemical composition within each silicate lump. At 30,000× magnification (corresponding to a scan area of $4 \times 5 \mu \mathrm{m}$ ), a semiquantitative chemical analysis of two of the silicate grains yielded a low sum of $40 \%$, probably a result of large amounts of interlayer $\mathrm{H}_{2} \mathrm{O}$ and porosity within the grains. The normalized composition of the grains was $60 \% \mathrm{SiO}_{2}, 14 \%$ $\mathrm{Al}_{2} \mathrm{O}_{3}, 15 \% \mathrm{FeO}, 6 \% \mathrm{MgO}, 2 \% \mathrm{CaO}$, and $2 \% \mathrm{~K}_{2} \mathrm{O}$, corresponding to an Fe-rich alumino-silicate, judged to be a clay mineral from its morphology. The analyses of the two grains are identical within the accuracy reported here.

One of the two grains, "A" (Plate 4) could be either an altered detrital grain or a diagenetic (authigenic) grain, although the grain shape suggests a detrital origin. Grain "B" (Plate 5) fills a microfossil shell and is probably authigenic.

\section{Occurrence of Color Bands Within the Sequence}

A possible climatic control on the occurrence of color bands would probably also influence the concentration of microfossils as reflected in grain-size distribution and control the isotopic composition of the pelagic fossils; however, no sign of climatic influence was found.

\section{Total Organic Carbon Contents}

The results of TOC analysis are listed in Table 2 and plotted in Figure 4. No well-defined relationship between the TOC content and the presence of color bands was seen.

\section{Grain Size}

The grain-size data listed in Table 2 and plotted in Figure 4 do not illustrate any obvious relationship between grain size and the presence of color bands. 

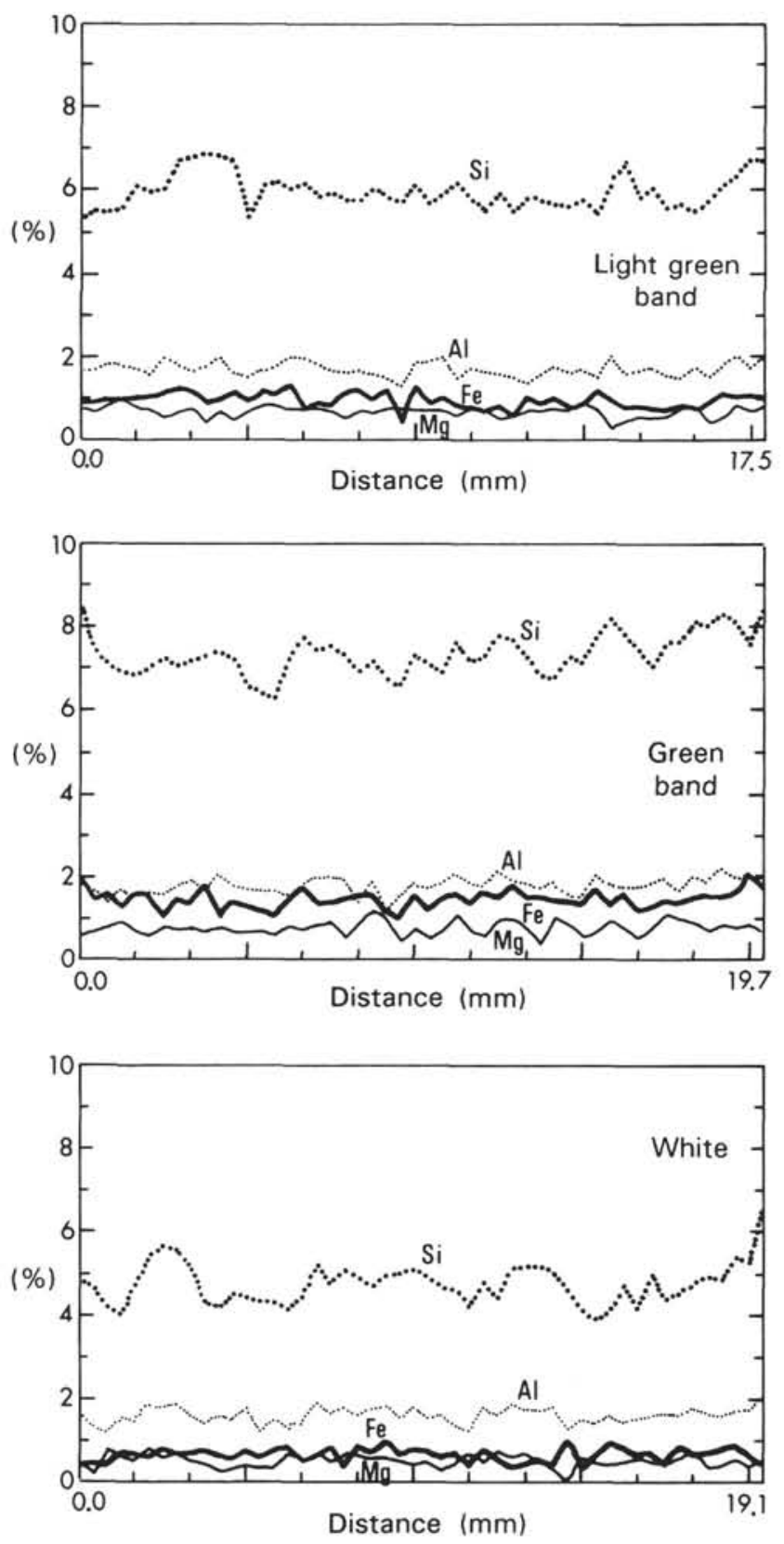

Figure 2. Microprobe profiles over Sample 130-807B-2H-5, 30-32 cm. Profiles are parallel to bands.

\section{Stable Isotopic Composition}

The $\delta^{18} \mathrm{O}$ and $\delta^{13} \mathrm{C}$ data are listed in Tables 3 and 4 and plotted in Figure 5. No obvious relationship between local isotopic signal and color bands was seen. In fact, variations between sample sets are generally greater than variations within a sample set.

Of the eight intervals of color bands plotted in Figure 6, four (A-D) date to the late Pleistocene, whereas the other four intervals date to the late Pliocene. According to the $\delta^{18} \mathrm{O}$ data, two of the upper Pleistocene intervals are interglacial sediments and two upper Pleistocene intervals were from sediments deposited during glacial periods. Four other intervals of color bands $(\mathrm{E}-\mathrm{H})$ are late Pliocene in age. Though a detailed isotopic stratigraphy is lacking for this interval, color bands in Groups $\mathrm{E}$ and $\mathrm{F}$ belong to sediments with relatively "light" (interglacial) $\delta^{18} \mathrm{O}$ values.
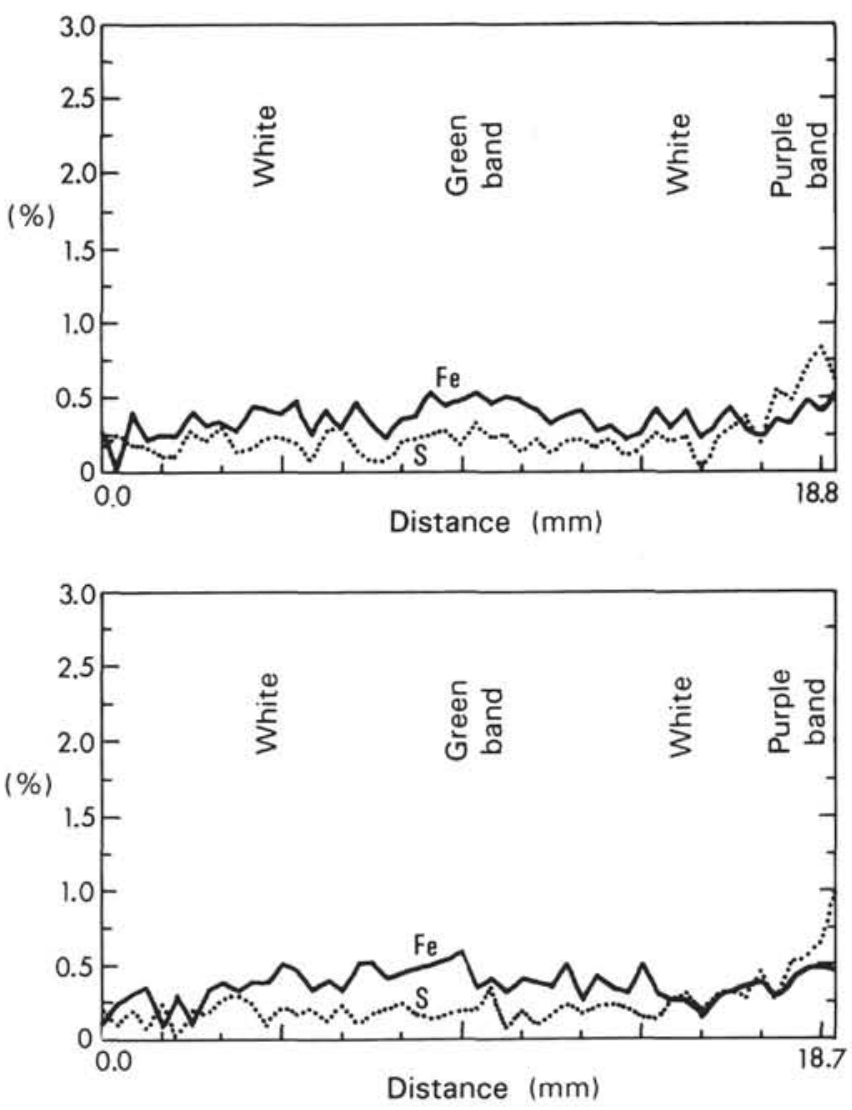

Figure 3. Microprobe profiles over Sample 130-807B-4H-6, 119-121 cm. Profiles are perpendicular to bands.

Surface-water productivity is reflected in the $\delta^{13} \mathrm{C}$ of the planktonic foraminifers. More positive planktonic $\delta^{13} \mathrm{C}$ suggests more productive waters and a larger organic matter rain to the seafloor. Upper Pleistocene color bands $\mathrm{A}$ and $\mathrm{C}$ are from sediments with significantly different planktonic foraminiferal $\delta^{13} \mathrm{C}$ values. Color Band $\mathrm{C}$ represents relatively high productivity. The $\delta^{13} \mathrm{C}$ of planktonic foraminifers from upper Pliocene color bands do not differ significantly. No consistent or significant variation appears to be present in the productivity recorded by these color bands.

\section{Spatial and Temporal Abundance}

The record of spatial and temporal distribution of the color bands should give clues to the possible volcanic or diagenetic origin of the bands. If the distribution of color bands can be correlated from site to site on the basis of age, then volcanic influence is suggested. If the color bands can be correlated from site to site on the basis of depth, then a diagenetic origin is indicated.

Results of counting green and purple bands separately in Hole 807A are presented in Figures 7A-7C. The number of green color bands does not correlate clearly with the number of purple bands, but for each color, low estimates consistently increase as the high estimates increase. Low estimates of color band abundance from photographs of the Hole 807A cores are compared with direct counts from the slabbed core surface in Figure 7D. The sum of the purple and green bands correlates well with the number estimated from the core photographs.

Low estimates of the temporal and spatial abundances of color bands are presented in Figure 8. The depth-age conversion is based on data from the Leg 130 site reports (Kroenke, Berger, Janecek, et al., 1991). The abundances of color bands are correlated between 

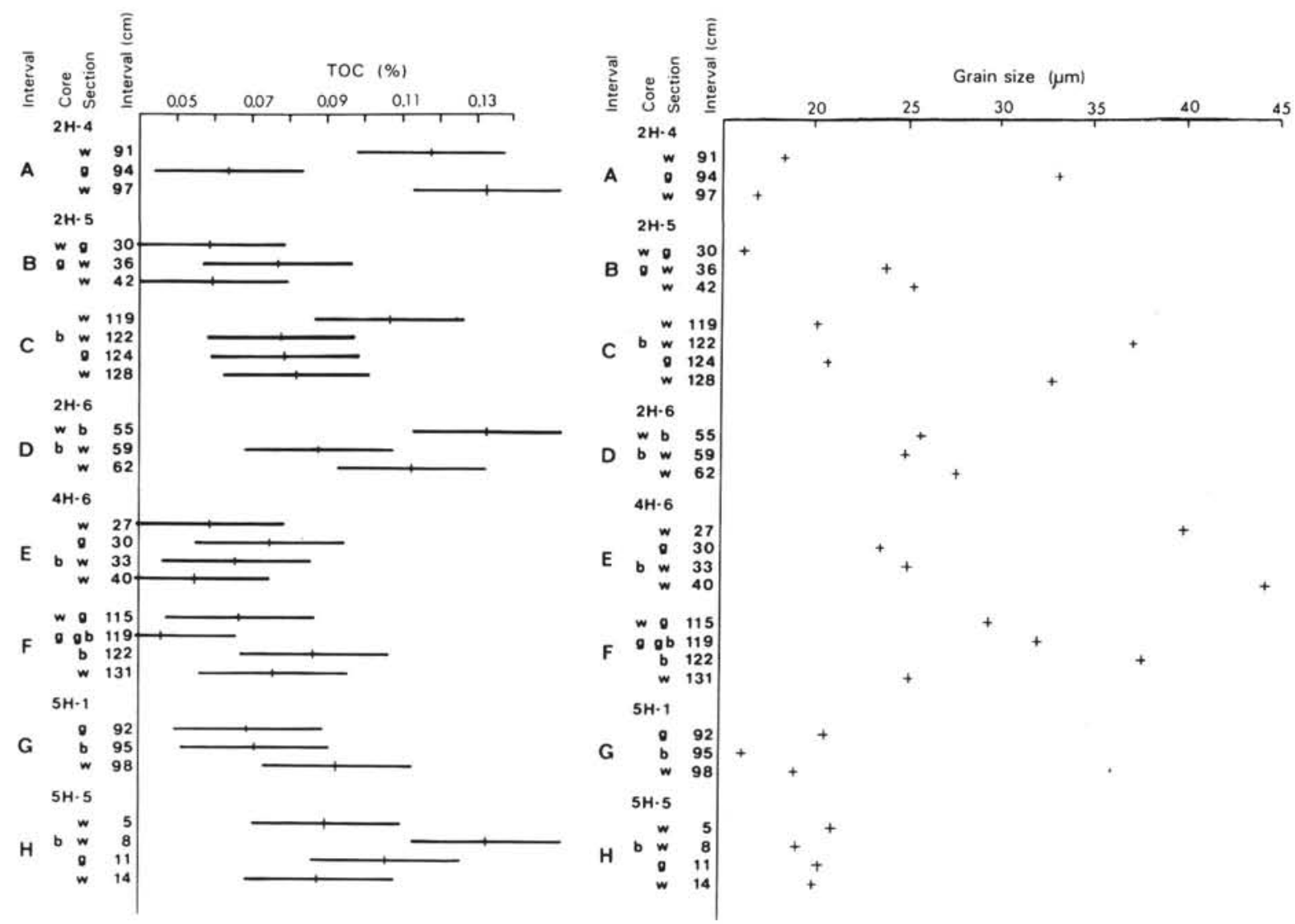

Figure 4. Total organic carbon and average grain size for bulk samples from Hole 807B. Sample codes given in Table 1. Average values are marked as data points, whereas the bar indicates \pm 1 standard deviation.

holes on the basis of age rather than depth, comparable to the relationship seen on the Lord Howe Rise (Fig. 9). For the bands on the Ontong Java Plateau, a distinct maximum is seen in all holes near $7 \mathrm{Ma}$, and distinct minima are at 9-10 and 17-20 Ma. The peaks and troughs in band abundance roughly correspond in age to those found at the Lord Howe Rise.

\section{DISCUSSION}

\section{Source of Color Banding}

Microprobe and BSE data indicate that the green bands contain finely disseminated $\mathrm{Fe}$ silicates, whereas the purple bands contain disseminated iron sulfide. The main difference between the green and the purple bands is not the concentration of Fe but, rather, whether the $\mathrm{Fe}$ is present in a silicate phase or in a sulfide.

The results of XRD analysis of residues after $\mathrm{HCl}$ leaching indicate that the residues are composed of fine-grained and/or poorly crystalline to amorphous components, as disseminated pyrite generally produces no peaks on diffractograms. This is in agreement with the small grain size of the iron sulfide $(<50 \mu \mathrm{m}$, commonly $<10 \mu \mathrm{m})$ and Fe-silicate (approximately $10 \mu \mathrm{m}$ ) particles detected by BSE and microprobe analysis.

\section{Formation of Color Bands}

From the isotope data (Fig. 6), no connection can be inferred between surface-water productivity, as indicated by the $\delta^{13} \mathrm{C}$ and color band formation. This agrees with the grain-size data, which indicate no relationship between average grain size (reflecting relative abun- dance of foraminifers) and the color bands. Thus, no indication exists that climatic factors govern the presence of color bands.

The lack of correlation between the numbers of green and purple bands (Fig. 7C) but the good correlation of the sum of green and purple bands between holes suggest a common origin for the two band types. The fact that the distribution of the bands is age dependent rather than depth dependent may indicate a primary sedimentary influence on their formation. As pointed out by Delaney et al. (1991), however, the pore-water chemistry also follows an age rather than a depth trend, probably caused by the inverse correlation between sediment supply and water depth. As a result, a diagenetic influence on the setting of color band formation cannot be ruled out. Nevertheless, the temporal distribution of bands on the Ontong Java Plateau is generally comparable with that observed at the Lord Howe Rise by Gardner et al. (1986). This suggests a common mode of origin, which is at least partly volcanic, as demonstrated by Gardner et al. (1986). Because petrographic data suggest a diagenetic or diagenetically overprinted sedimentary origin for the color bands, modifications of volcanic grains appear to be the most likely source of the green and purple bands. Thus, the purple bands probably represent diagenetically altered green bands. The narrowing of bands of both colors with depth results from compaction and local chemical reorganization.

The similar Fe contents in the greenish gray and pale purple bands indicate that the present green bands do not serve as the source of $\mathrm{Fe}$ for nearby Fe-sulfide concentrations. The difference in color is rather a consequence of redox processes that locally dissolve silicates (from green bands that have now been modified to purple) and reprecipitate iron sulfide, but do not necessarily transport Fe. The influence of redox processes on the color of the bands is clearly 
Table 2. Total organic carbon and carbonate, and average grain sizes, Hole 807B.

\begin{tabular}{|c|c|c|c|c|c|c|}
\hline Interval & $\begin{array}{l}\text { Core, section, } \\
\text { interval }(\mathrm{cm})\end{array}$ & $w$ & d & $\begin{array}{c}\mathrm{CaCO}_{3} \\
(\%)\end{array}$ & $\begin{array}{l}\text { TOC } \\
(\%)\end{array}$ & $\begin{array}{l}\text { Size } \\
(\mu \mathrm{m})\end{array}$ \\
\hline A & $2 \mathrm{H}-4,91-93$ & & & 86.0 & 0.12 & 18.4 \\
\hline A & $2 \mathrm{H}-4,94-96$ & $\mathrm{~g}$ & $\mathrm{~g}$ & 89.8 & 0.06 & 33.1 \\
\hline A & $2 \mathrm{H}-4,97-99$ & & & 81.7 & 0.13 & 16.9 \\
\hline B & $2 \mathrm{H}-5,30-32$ & & $\mathrm{~g}$ & 90.3 & 0.06 & 16.2 \\
\hline B & $2 \mathrm{H}-5,36-38$ & $\mathrm{~g}$ & & 87.8 & 0.08 & 23.8 \\
\hline B & $2 \mathrm{H}-5,42-44$ & & & 91.1 & 0.06 & 25.3 \\
\hline $\mathrm{C}$ & $2 \mathrm{H}-5,119-121$ & & & 83.9 & 0.11 & 20.1 \\
\hline $\mathrm{C}$ & $2 \mathrm{H}-5,122-124$ & b & & 89.6 & 0.08 & 37.1 \\
\hline C & $2 \mathrm{H}-5,124-126$ & $\mathrm{~g}$ & $\mathrm{~g}$ & 84.6 & 0.08 & 20.7 \\
\hline $\mathrm{C}$ & $2 \mathrm{H}-5,128-130$ & & & 89.8 & 0.08 & 32.7 \\
\hline D & $2 \mathrm{H}-6,55-57$ & & b & 82.7 & 0.13 & 25.7 \\
\hline D & $2 \mathrm{H}-6,59-61$ & b & & 88.1 & 0.09 & 24.9 \\
\hline D & $2 \mathrm{H}-6,62-64$ & & & 87.4 & 0.11 & 27.6 \\
\hline $\mathrm{E}$ & $4 \mathrm{H}-6,27-29$ & & & 88.4 & 0.06 & 39.8 \\
\hline $\mathrm{E}$ & $4 \mathrm{H}-6,30-32$ & $\mathrm{~g}$ & g & 88.8 & 0.08 & 23.6 \\
\hline $\mathrm{E}$ & $4 \mathrm{H}-6,33-35$ & $\mathrm{~b}$ & & 87.4 & 0.07 & 25.0 \\
\hline $\mathrm{E}$ & $4 \mathrm{H}-6,40-42$ & & & 88.8 & 0.06 & 44.2 \\
\hline $\mathrm{F}$ & $4 \mathrm{H}-6,115-117$ & & $\mathrm{~g}$ & 89.4 & 0.07 & 29.4 \\
\hline $\mathrm{F}$ & $4 \mathrm{H}-6,119-121$ & $\mathrm{~g}$ & b & 91.1 & 0.05 & 32.0 \\
\hline $\mathrm{F}$ & $4 \mathrm{H}-6,122-124$ & $\mathrm{~b}$ & b & 78.2 & 0.09 & 37.6 \\
\hline $\mathrm{F}$ & $4 \mathrm{H}-6,131-133$ & & & 87.7 & 0.08 & 25.1 \\
\hline G & $5 \mathrm{H}-1,92-94$ & $\mathrm{~g}$ & $\mathrm{~g}$ & 89.0 & 0.07 & 20.5 \\
\hline G & $5 \mathrm{H}-1,95-97$ & $\mathrm{~b}$ & b & 90.2 & 0.07 & 16.2 \\
\hline G & $5 \mathrm{H}-1,98-100$ & & & 86.6 & 0.09 & 19.0 \\
\hline $\mathrm{H}$ & $5 \mathrm{H}-5,5-7$ & & & 90.8 & 0.09 & 20.5 \\
\hline $\mathrm{H}$ & $5 \mathrm{H}-5,8-10$ & b & & 85.7 & 0.13 & 19.1 \\
\hline $\mathrm{H}$ & $5 \mathrm{H}-5,11-13$ & $\mathrm{~g}$ & $\mathrm{~g}$ & 90.2 & 0.11 & 20.3 \\
\hline $\mathrm{H}$ & $5 \mathrm{H}-5,14-16$ & & & 91.7 & 0.09 & 20.0 \\
\hline
\end{tabular}

Notes: $\mathrm{g}=$ samples with green bands, $\mathrm{b}=$ samples with purple (blue) bands as observed on wet surface (w) during initial sampling and on the dry, epoxy-impregnated, polished surface (d).

indicated by the intersection of a halo around a burrow and a color band in Hole 807A (Kroenke, Berger, Janecek, et al., 1991), where the color band is greenish outside the halo and pale purple inside the halo (Plate 2, Fig. 2).

The color bands, therefore, represent a multistage diagenetic history. A supply of volcanic ash? is acted on during very early diagenesis to produce a (green?) color band; the actual color of the band may subsequently be affected by slightly later early diagenesis (e.g., the migration of a redox front away from a burrow). Later diagenesis is demonstrated by compaction and chemical reorganization of the bands.

The iron-sulfide-rich purple bands point to relatively reducing conditions. Delaney et al. (1991) concluded, from pore-water analysis from Ontong Java Plateau cores, that the depletion in sulfate relative to seawater was probably limited by a paucity of organic matter. The low amounts of organic matter found in these sediments at present prevent us from evaluating the importance of temporal variations in organic matter supply and the consequent inhomogeneous distribution of organic matter within the sediments, which could produce redox levels within the sediment reflected by the varying colors of the bands.

\section{SUMMARY}

Oxygen isotope data show that the color bands occur in glacial as well as interglacial sediments. Carbon isotope and grain-size data do not indicate that the bands developed because of significant variations in productivity. Thus, climatic influences on color band formation are not suggested.

The abundance of color bands can be correlated from hole to hole on an age rather than a depth scale (Fig. 8). The age distribution is comparable with the one found by Gardner et al. (1986) on the Lord Howe Rise. This indicates, at least partly, a common mode of origin for the bands, arising from the alteration of volcanic detritus.

Atomic absorption spectroscopy, electron microscopy, and microprobe analysis show that the purple bands contain finely disseminated authigenic iron sulfide, whereas the green bands contain finely disseminated Fe-bearing alumino-silicate, judged to be clay on the basis of particle morphology. The clay may represent altered volcanic grains and is seen both as small grains (Plate 4, Fig. 1) and as diagenetic fillings of fossil shells (Plate 5, Fig. 1).

The observation of a color band changing from green to purple at a pyritic halo centered on a burrow, the lack of correlation between the abundance of green and purple bands, the frequent observation of color bands that cross burrows, and the narrowing of color bands with depth point to a significant diagenetic overprint on the bands and also indicate a common source for the green and purple bands.

Therefore, the green bands are apparently characterized by the presence of Fe-bearing clays and probably represent altered volcanic ash, whereas the purple bands are characterized by the presence of Fe-sulfides and probably represent green bands that have been altered under locally reducing conditions.

\section{ACKNOWLEDGMENTS}

Help and advice are acknowledged from J. Rønsbo, M. Christensen, J. Fløng, B. Frydenlund, V. Knudsen, G. Krarup, S. Nguyen, A. Steffensen, and I. Søndergaard.

\section{REFERENCES}

Andrews, J.E., Packham, G., et al., 1975. Init. Repts. DSDP, 30: Washington (U.S. Govt. Printing Office).

Craig, H., 1957. Isotope standards for C and $\mathrm{O}$ and corrections for mass spectrometric analysis of CO2. Geochim. Cosmochim. Acta, 12:133-149.

Delaney, M.L., and Shipboard Scientific Party, 1991. Inorganic geochemistry summary. In Kroenke, L.W., Berger, W.H., Janecek, T.R., et al., Proc. ODP, Init. Repts., 130: College Station, TX (Ocean Drilling Program), 549-551.

Gardner, J.V., Nelson, C.S., and Baker, P.A., 1986. Distribution and character of pale green laminae in sediment from Lord Howe Rise: a probable late Neogene and Quaternary tephrostratigraphic record. In Kennett, J.P., von der Borch, C.C., et al., Init. Repts. DSDP, 90: Washington (U.S. Govt. Printing Office), 1145-1159.

Kennett, J.P., von der Borch, C.C., et al., 1986. Init. Repts. DSDP, 90: Washington (U.S. Govt. Printing Office).

Supko, P.R., Perch-Nielsen, K., et al., 1977. Init. Repts. DSDP, 39: Washington (U.S. Govt. Printing Office).

Winterer, E.L., Riedel, W.R., et al., 1971. Init. Repts. DSDP, 7, Pt. 1: Washington (U.S. Govt. Printing Office).

Date of initial receipt: 6 September 1991

Date of acceptance: 22 June 1992

Ms 130B-007 


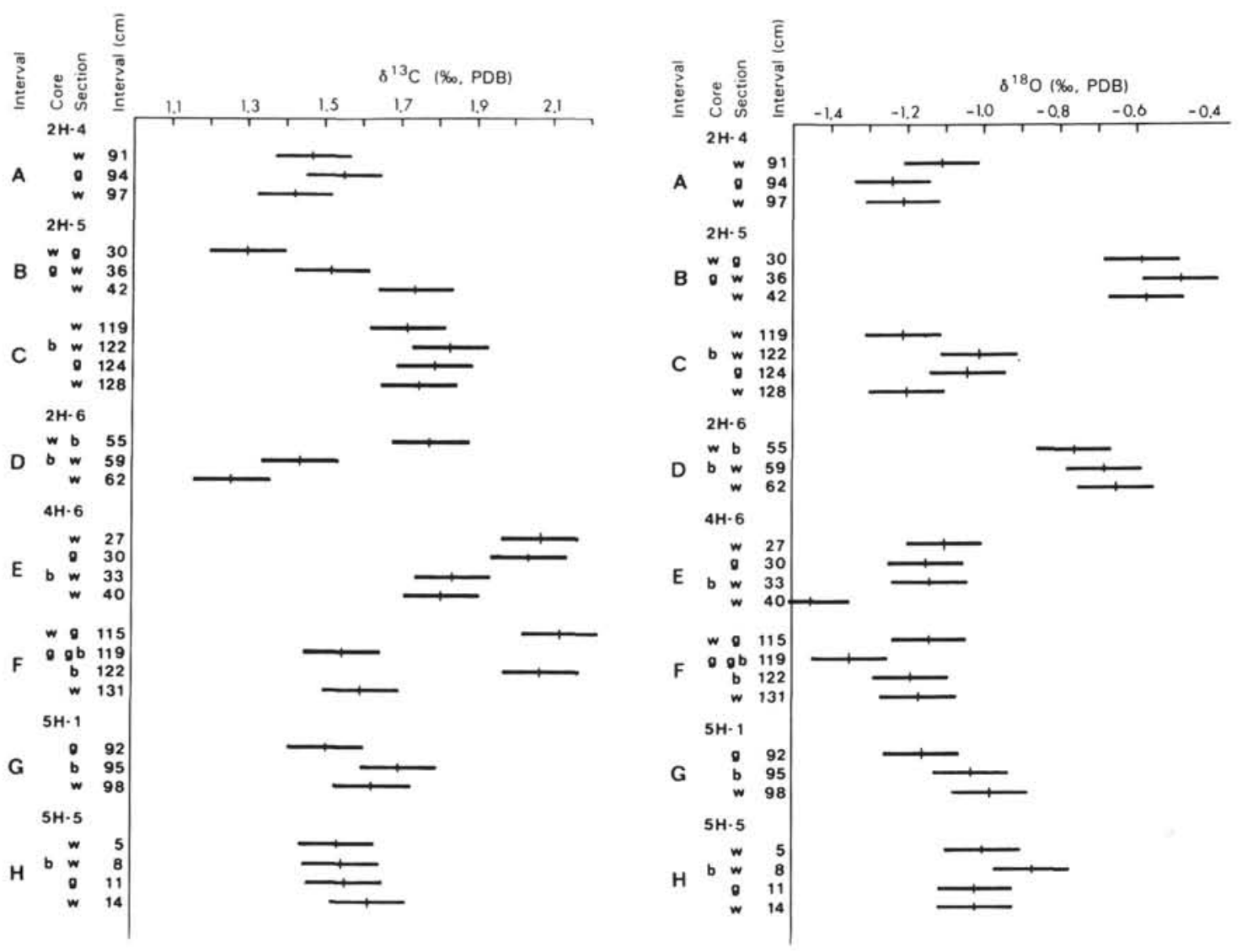

Figure 5. Carbon and oxygen isotope data for Globigerinoides trilobus, Hole 807B. Average values are marked as data points, whereas the bar indicates \pm 1 standard deviation.

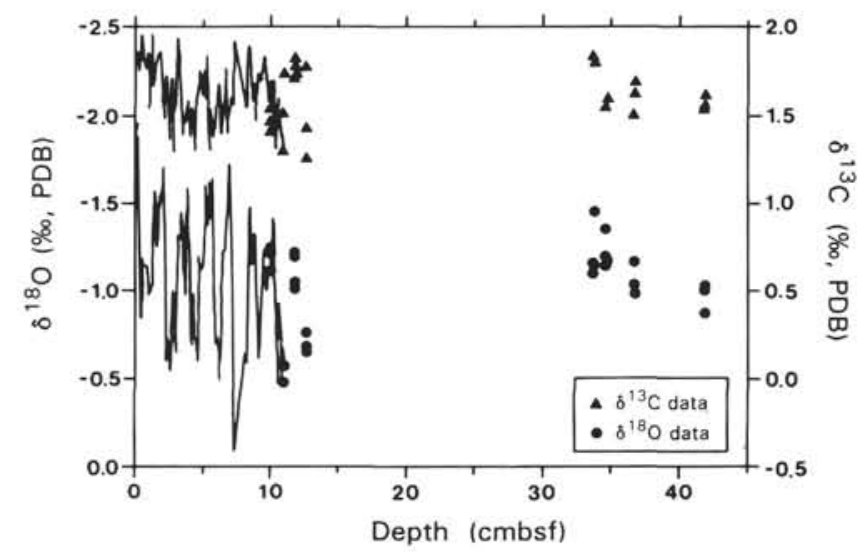

Figure 6. Isotope data plotted on a corrected meters below seafloor scale (cmbsf). 
Table 3. Average carbon and oxygen isotope data for Globigerinoides trilobus, Hole 807B.

\begin{tabular}{|c|c|c|c|c|c|c|c|c|}
\hline Interval & $\begin{array}{l}\text { Core, section, } \\
\text { interval }(\mathrm{cm})\end{array}$ & $\begin{array}{l}\text { Depth } \\
\text { (mbsf) }\end{array}$ & $\begin{array}{c}\text { Corrected } \\
\text { depth } \\
\text { (mbsf) }\end{array}$ & Transducer & $\left({ }^{13} \mathrm{C}, \mathrm{PDB}\right)$ & $\begin{array}{c}{ }^{18} \mathrm{O} \\
(\% \infty, \mathrm{PDB})\end{array}$ & $\begin{array}{l}\text { Age } \\
(\mathrm{Ma})\end{array}$ & Replicates \\
\hline A & $2 \mathrm{H}-4,9 \mathrm{I}-93$ & 8.51 & 9.97 & 4.1 & 1.47 & -1.11 & 0.593 & \\
\hline A & $2 \mathrm{H}-4,94-96$ & 8.54 & 10.00 & 5.0 & 1.55 & -1.24 & 0.594 & 1 \\
\hline A & $2 \mathrm{H}-4,97-99$ & 8.57 & 10.03 & 5.6 & 1.42 & -1.21 & 0.596 & 1 \\
\hline B & $2 \mathrm{H}-5,30-32$ & 9.40 & 10.86 & 5.9 & 1.30 & -0.58 & 0.650 & \\
\hline B & $2 \mathrm{H}-5,36-38$ & 9.46 & 10.92 & 5.2 & 1.52 & -0.48 & 0.654 & 1 \\
\hline B & $2 \mathrm{H}-5,42-44$ & 9.52 & 10.98 & 6.3 & 1.74 & -0.57 & 0.657 & \\
\hline $\mathrm{C}$ & $2 \mathrm{H}-5,119-121$ & 10.29 & 11.75 & 5.0 & 1.72 & -1.21 & 0.703 & 1 \\
\hline $\mathrm{C}$ & $2 \mathrm{H}-5,122-124$ & 10.32 & 11.78 & 5.6 & 1.83 & -1.01 & 0.705 & \\
\hline C & $2 \mathrm{H}-5,124-126$ & 10.34 & 11.80 & 5.6 & 1.79 & -1.04 & 0.706 & \\
\hline $\mathrm{C}$ & $2 \mathrm{H}-5,128-130$ & 10.38 & 11.84 & 6.1 & 1.75 & -1.20 & 0.709 & 1 \\
\hline D & $2 \mathrm{H}-6,55-57$ & 11.15 & 12.61 & 6.7 & 1.78 & -0.76 & 0.752 & \\
\hline D & $2 \mathrm{H}-6,59-61$ & 11.19 & 12.65 & 6.1 & 1.44 & -0.68 & 0.754 & 1 \\
\hline D & $2 \mathrm{H}-6,62-64$ & 11.22 & 12.68 & 5.9 & 1.26 & -0.65 & 0.756 & \\
\hline $\mathrm{E}$ & $4 \mathrm{H}-6,27-29$ & 29.87 & 33.66 & 5.6 & 2.07 & -1.10 & 2.005 & I \\
\hline $\mathrm{E}$ & $4 \mathrm{H}-6,30-32$ & 29.90 & 33.69 & 4.8 & 2.04 & -1.15 & 2.007 & 1 \\
\hline $\mathrm{E}$ & $4 \mathrm{H}-6,33-35$ & 29.93 & 33.72 & 4.3 & 1.84 & -1.14 & 2.008 & 1 \\
\hline $\mathrm{E}$ & $4 \mathrm{H}-6,40-42$ & 30.00 & 33.79 & 4.6 & 1.81 & -1.45 & 2.012 & 2 \\
\hline $\mathrm{F}$ & $4 \mathrm{H}-6,115-117$ & 30.75 & 34.54 & 5.2 & 2.12 & -1.14 & 2.049 & 2 \\
\hline $\mathrm{F}$ & $4 \mathrm{H}-6,119-121$ & 30.79 & 34.58 & 5.4 & 1.55 & -1.35 & 2.051 & 1 \\
\hline $\mathrm{F}$ & $4 \mathrm{H}-6,122-124$ & 30.82 & 34.61 & 3.0 & 2.07 & -1.19 & 2.052 & 1 \\
\hline $\mathrm{F}$ & $4 \mathrm{H}-6,131-133$ & 30.91 & 34.70 & 5.0 & 1.60 & -1.17 & 2.056 & 1 \\
\hline G & $5 \mathrm{H}-1,92-94$ & 32.52 & 36.69 & 5.6 & 1.51 & -1.16 & 2.154 & 1 \\
\hline G & $5 \mathrm{H}-1,95-97$ & 32.55 & 36.72 & 5.6 & 1.70 & $-1,03$ & 2.155 & 1 \\
\hline G & $5 \mathrm{H}-1,90-100$ & 32.58 & 36.75 & 5.8 & 1.63 & -0.98 & 2.157 & 1 \\
\hline $\mathrm{H}$ & $5 \mathrm{H}-5,5-7$ & 37.65 & 41.82 & 5.4 & 1.54 & -1.00 & 2.395 & 1 \\
\hline $\mathrm{H}$ & $5 \mathrm{H}-5,8-10$ & 37.68 & 41.85 & 5.6 & 1.55 & -0.87 & 2.396 & 1 \\
\hline $\mathrm{H}$ & $5 H-5,11-13$ & 37.71 & 41.88 & 6.2 & 1.56 & -1.02 & 2.398 & 1 \\
\hline $\mathrm{H}$ & $5 \mathrm{H}-5,14-16$ & 37.74 & 41.91 & 5.2 & 1.62 & -1.02 & 2.399 & $i$ \\
\hline
\end{tabular}

Notes: Corrected depth from GRAPE and magnetic susceptibility data; preliminary age based on biostratigraphy and oxygen-isotope stratigraphy. 
Table 4. Globigerinoides trilobus replicate isotope data, Hole 807B.

\begin{tabular}{|c|c|c|c|c|c|c|c|}
\hline Interval & $\begin{array}{l}\text { Core, section, } \\
\text { interval }(\mathrm{cm})\end{array}$ & $\begin{array}{l}\text { Depth } \\
\text { (mbsf) }\end{array}$ & $\begin{array}{c}\text { Corrected } \\
\text { depth } \\
\text { (mbsf) }\end{array}$ & Transducer & $\begin{array}{c}{ }^{13} \mathrm{C} \\
(\% \infty, \text { PDB })\end{array}$ & $\begin{array}{c}{ }^{18} \mathrm{O} \\
(\%,, \mathrm{PDB})\end{array}$ & $\begin{array}{l}\text { Age } \\
\text { (Ma) }\end{array}$ \\
\hline A & $2 \mathrm{H}-4,94-96$ & 8.54 & 10.00 & 5.9 & 1.54 & -1.32 & 0.594 \\
\hline $\mathrm{A}$ & $2 \mathrm{H}-4,94-96$ & 8.54 & 10.00 & 4.1 & 1.57 & -1.17 & 0.594 \\
\hline A & $2 \mathrm{H}-4,97-99$ & 8.57 & 10.03 & 5.2 & 1.42 & -1.29 & 0.596 \\
\hline A & $2 \mathrm{H}-4,97-99$ & 8.57 & 10.03 & 5.9 & 1.43 & -1.13 & 0.596 \\
\hline B & $2 \mathrm{H}-5,36-38$ & 9.46 & 10.92 & 4.8 & 1.71 & -0.40 & 0.654 \\
\hline B & $2 \mathrm{H}-5,36-38$ & 9.46 & 10.92 & 5.6 & 1.33 & -0.57 & 0.654 \\
\hline C & $2 \mathrm{H}-5,119-121$ & 10.29 & 11.75 & 4.4 & 1.73 & -1.18 & 0.703 \\
\hline C & $2 \mathrm{H}-5,119-121$ & 10.29 & 11.75 & 5.6 & 1.72 & -1.25 & 0.703 \\
\hline C & $2 \mathrm{H}-5,128-130$ & 10.38 & 11.84 & 5.9 & 1.94 & -1.21 & 0.709 \\
\hline C & $2 \mathrm{H}-5,128-130$ & 10.38 & 11.84 & 6.3 & 1.57 & -1.19 & 0.709 \\
\hline D & $2 \mathrm{H}-6,59-61$ & 11.19 & 12.65 & 6.3 & 1.58 & -0.62 & 0.754 \\
\hline D & $2 \mathrm{H}-6,59-61$ & 11.19 & 12.65 & 5.9 & 1.31 & -0.74 & 0.754 \\
\hline E & $4 \mathrm{H}-6,27-29$ & 29.87 & 33.66 & 5.2 & 2.20 & -1.05 & 2.005 \\
\hline $\mathrm{E}$ & $4 \mathrm{H}-6,27-29$ & 29.87 & 33.66 & 5.9 & 1.94 & -1.16 & 2.005 \\
\hline E & $4 \mathrm{H}-6,30-32$ & 29.90 & 33.69 & 4.8 & 2.40 & -1.03 & 2.007 \\
\hline E & $4 \mathrm{H}-6,30-32$ & 29.90 & 33.69 & 4.8 & 1.68 & -1.27 & 2.007 \\
\hline E & $4 \mathrm{H}-6,33-35$ & 29.93 & 33.72 & 4.4 & 2.11 & -0.97 & 2.008 \\
\hline $\mathrm{E}$ & $4 \mathrm{H}-6,33-35$ & 29.93 & 33.72 & 4.1 & 1.57 & -1.30 & 2.008 \\
\hline E & $4 \mathrm{H}-6,40-42$ & 30.00 & 33.79 & 5.6 & 1.86 & -0.64 & 2.012 \\
\hline $\mathrm{E}$ & $4 \mathrm{H}-6,40-42$ & 30.00 & 33.79 & 4.4 & 1.93 & -1.74 & 2.012 \\
\hline E & $4 \mathrm{H}-6,40-42$ & 30.00 & 33.79 & 4.8 & 1.68 & -1.16 & 2.012 \\
\hline $\mathrm{F}$ & $4 \mathrm{H}-6,115-117$ & 30.75 & 34.54 & 5.2 & 2.09 & -1.21 & 2.049 \\
\hline $\mathrm{F}$ & $4 \mathrm{H}-6,115-117$ & 30.75 & 34.54 & 6.3 & 2.33 & -0.95 & 2.049 \\
\hline $\mathrm{F}$ & $4 \mathrm{H}-6,115-117$ & 30.75 & 34.54 & 4.1 & 1.94 & -1.25 & 2.049 \\
\hline $\mathrm{F}$ & $4 \mathrm{H}-6,119-121$ & 30.79 & 34.58 & 5.6 & 1.26 & -1.53 & 2.051 \\
\hline $\mathrm{F}$ & $4 \mathrm{H}-6,119-121$ & 30.79 & 34.58 & 5.2 & 1.84 & -1.18 & 2.051 \\
\hline $\mathrm{F}$ & $4 \mathrm{H}-6,122-124$ & 30.82 & 34.61 & 1.5 & 2.22 & -1.02 & 2.052 \\
\hline $\mathrm{F}$ & $4 \mathrm{H}-6,122-124$ & 30.82 & 34.61 & 4.4 & 1.93 & -1.36 & 2.052 \\
\hline $\mathrm{F}$ & $4 \mathrm{H}-6,131-133$ & 30.91 & 34.70 & 5.2 & 1.62 & -1.16 & 2.056 \\
\hline $\mathrm{F}$ & $4 \mathrm{H}-6,131-133$ & 30.91 & 34.70 & 4.8 & 1.59 & -1.19 & 2.056 \\
\hline G & $5 \mathrm{H}-1,92-94$ & 32.52 & 36.69 & 5.6 & 1.44 & -1.13 & 2.154 \\
\hline G & $5 \mathrm{H}-1,92-94$ & 32.52 & 36.69 & 5.6 & 1.58 & -1.19 & 2.154 \\
\hline G & $5 \mathrm{H}-1,95-97$ & 32.55 & 36.72 & 5.6 & 1.69 & -1.01 & 2.155 \\
\hline G & $5 \mathrm{H}-1,95-97$ & 32.55 & 36.72 & 5.6 & 1.71 & -1.06 & 2.155 \\
\hline G & $5 \mathrm{H}-1,98-100$ & 32.58 & 36.75 & 5.9 & 1.63 & -0.95 & 2.157 \\
\hline G & $5 \mathrm{H}-1,98-100$ & 32.58 & 36.75 & 5.6 & 1.63 & -1.02 & 2.157 \\
\hline $\mathrm{H}$ & $5 \mathrm{H}-5,5-7$ & 37.65 & 41.82 & 5.6 & 1.52 & -1.12 & 2.395 \\
\hline $\mathrm{H}$ & $5 \mathrm{H}-5,5-7$ & 37.65 & 41.82 & 5.2 & 1.57 & -0.89 & 2.395 \\
\hline $\mathrm{H}$ & $5 \mathrm{H}-5,8-10$ & 37.68 & 41.85 & 5.6 & 1.43 & -0.90 & 2.396 \\
\hline $\mathrm{H}$ & $5 \mathrm{H}-5,8-10$ & 37.68 & 41.85 & 5.6 & 1.67 & -0.84 & 2.396 \\
\hline $\mathrm{H}$ & $5 \mathrm{H}-5,11-13$ & 37.71 & 41.88 & 5.6 & 1.44 & -1.13 & 2.398 \\
\hline $\mathrm{H}$ & $5 \mathrm{H}-5,11-13$ & 37.71 & 41.88 & 6.7 & 1.69 & -0.91 & 2.398 \\
\hline $\mathrm{H}$ & $5 \mathrm{H}-5,14-16$ & 37.74 & 41.91 & 5.2 & 1.47 & -0.90 & 2.399 \\
\hline $\mathrm{H}$ & $5 \mathrm{H}-5,14-16$ & 37.74 & 41.91 & 5.2 & 1.77 & -1.15 & 2.399 \\
\hline
\end{tabular}


A

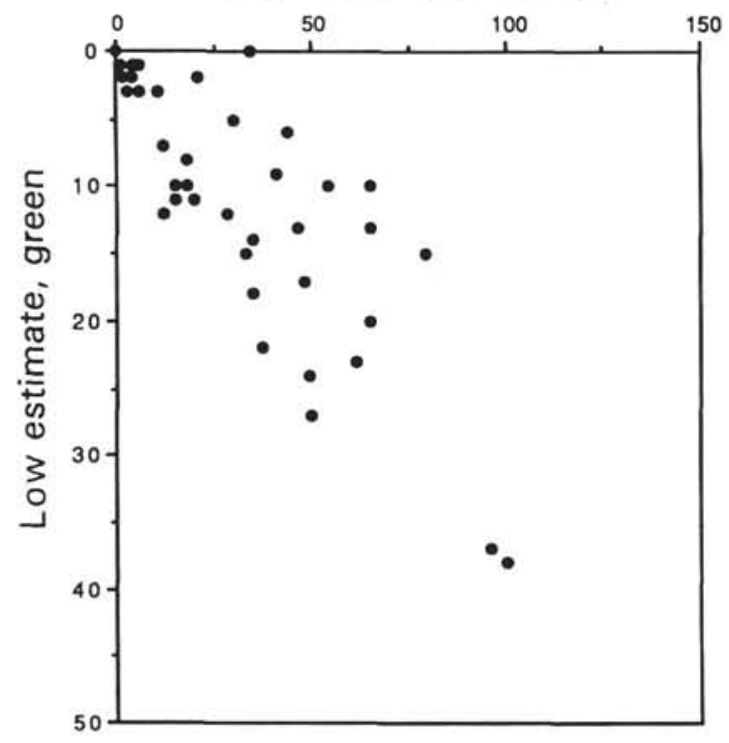

C

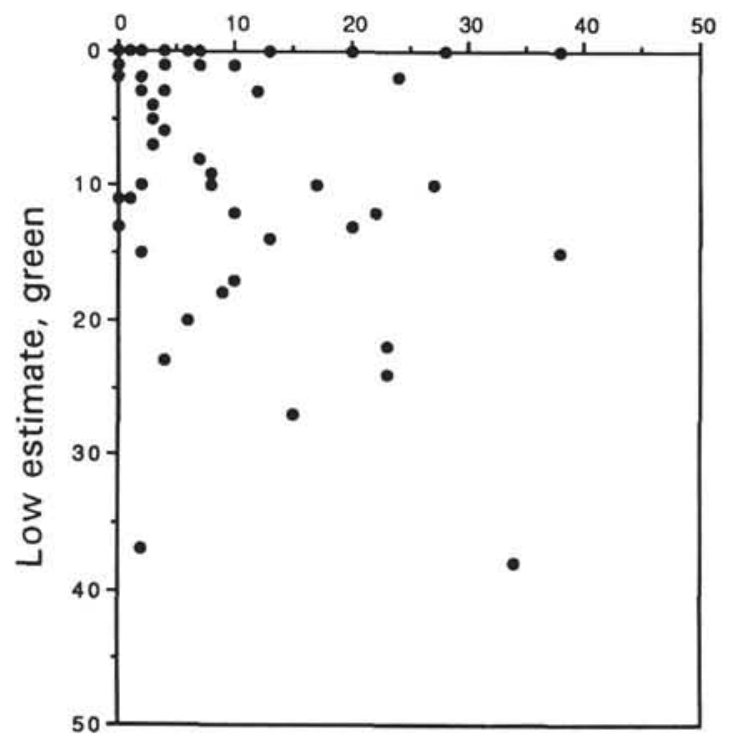

B

High estimate, purple

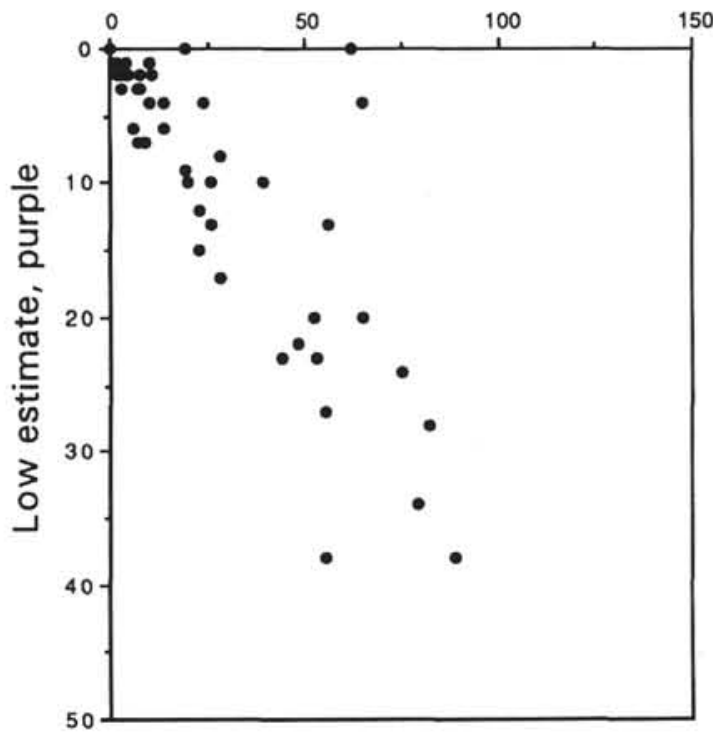

D Color bands per meter, low estimate

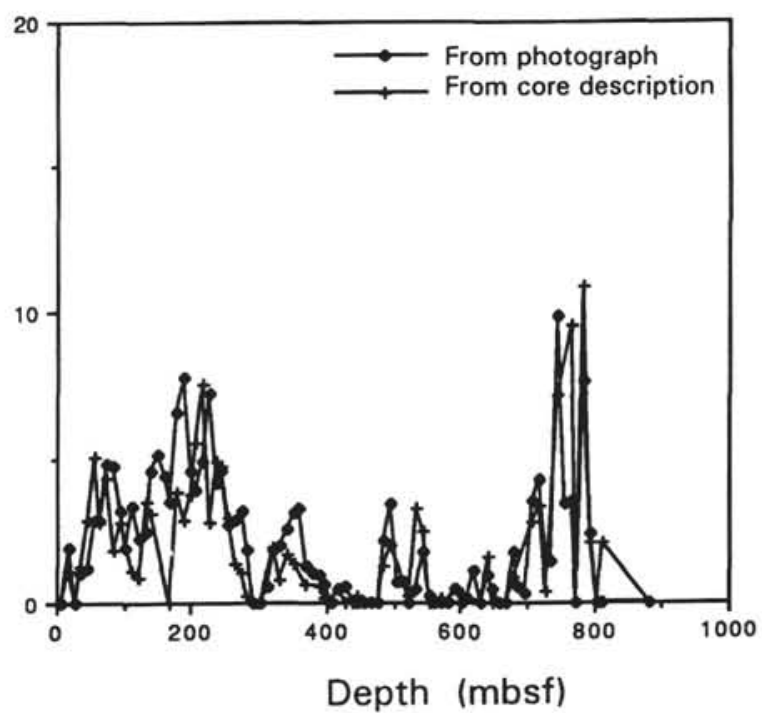

Figure 7. Color bands counted per section during the initial core description of Hole 807A. A. Green color bands. B. Purple color bands. C. Low estimates of purple vs. green bands. D. Comparison of color bands counted from photographs, with the sum of green and purple bands counted during the initial core description. 
I.L. LIND ET AL.
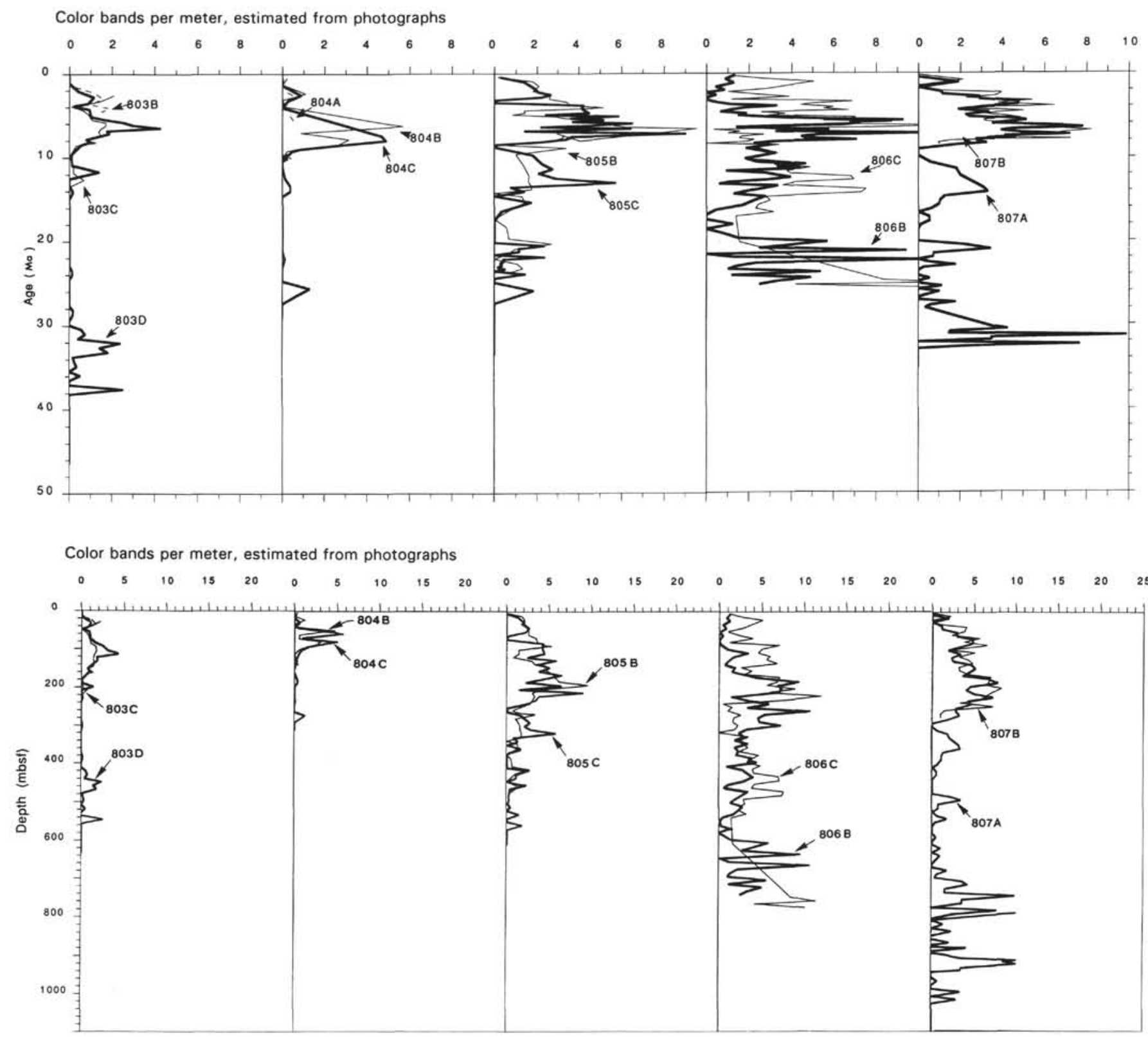

Figure 8. Abundance (low estimate) of color bands vs. age and depth below seafloor. Abundance is number of bands per well-preserved meter. 

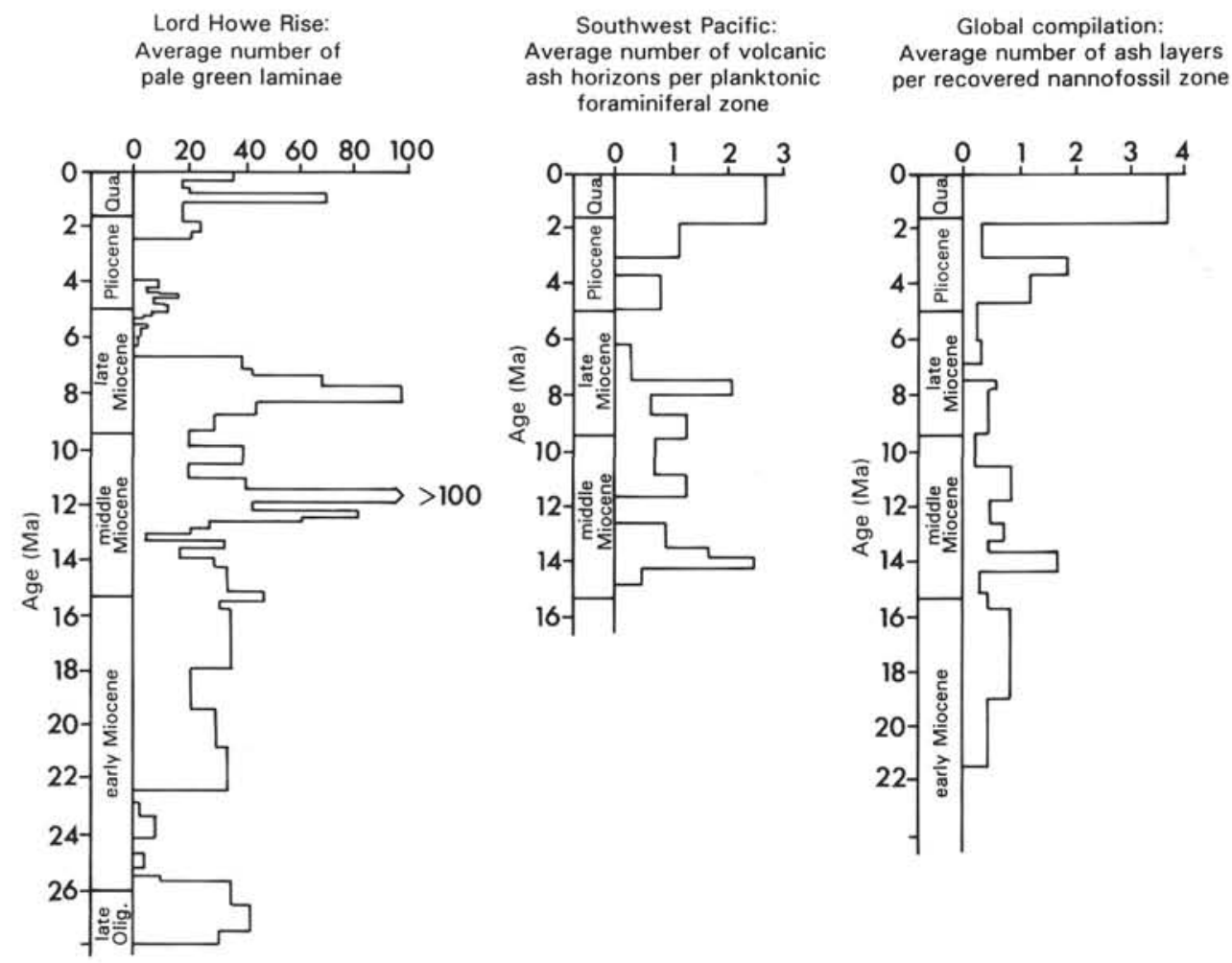
Ontong Java Plateau:
Number of color bands
per recovered meter foraminiferal zone
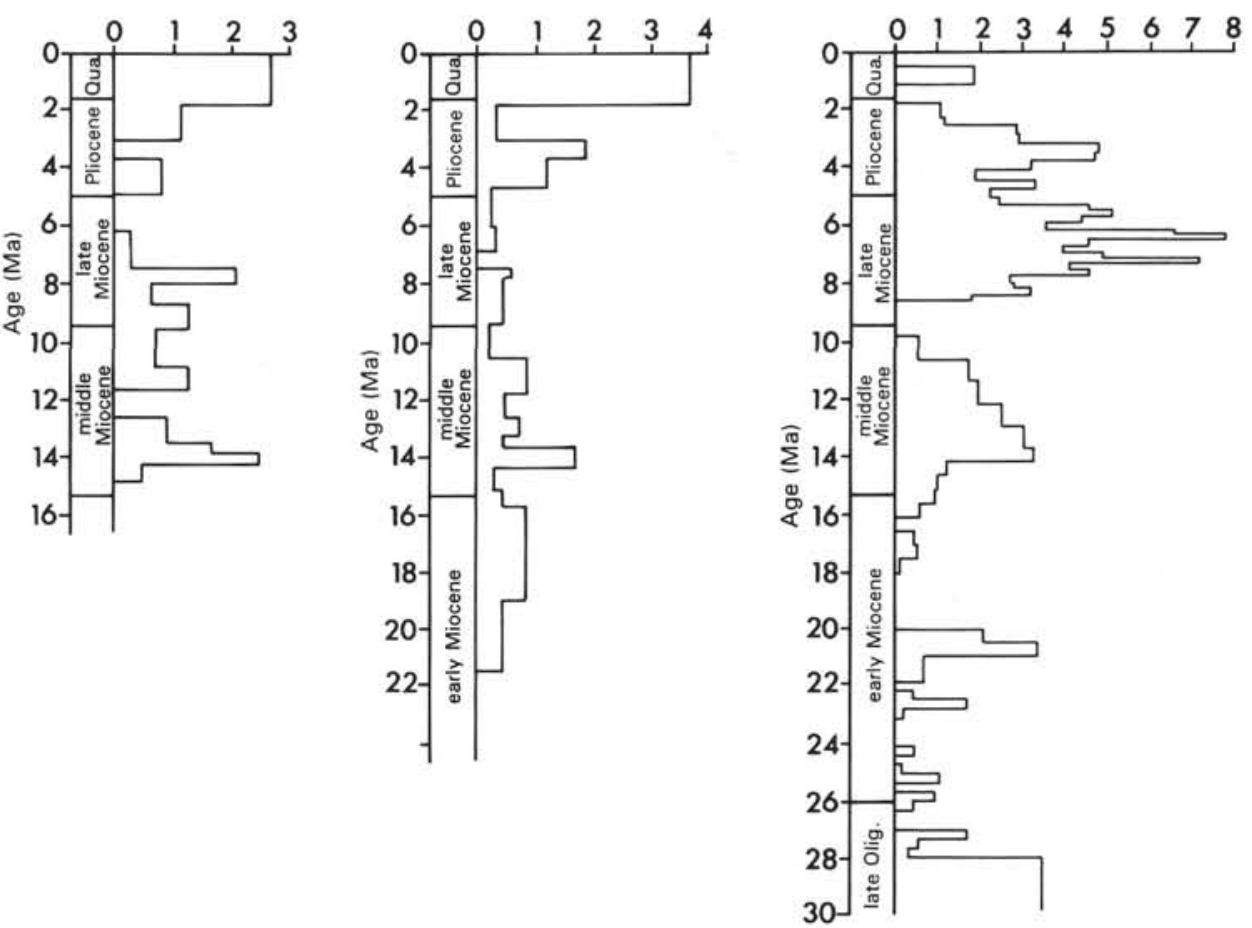

Figure 9. Distribution of pale green laminae on the Lord Howe Rise, the distribution of discrete volcanic ash layers from the southwest Pacific, and the global distribution of volcanic ash. Redrawn to the nannofossil zone-age conversion of Kroenke, Berger, Janecek, et al. (1991) after Gardner et al. (1986). To the right, distribution of color bands on the Ontong Java Plateau (Site 807, low estimate). 


\section{I.L. LIND ET AL.}
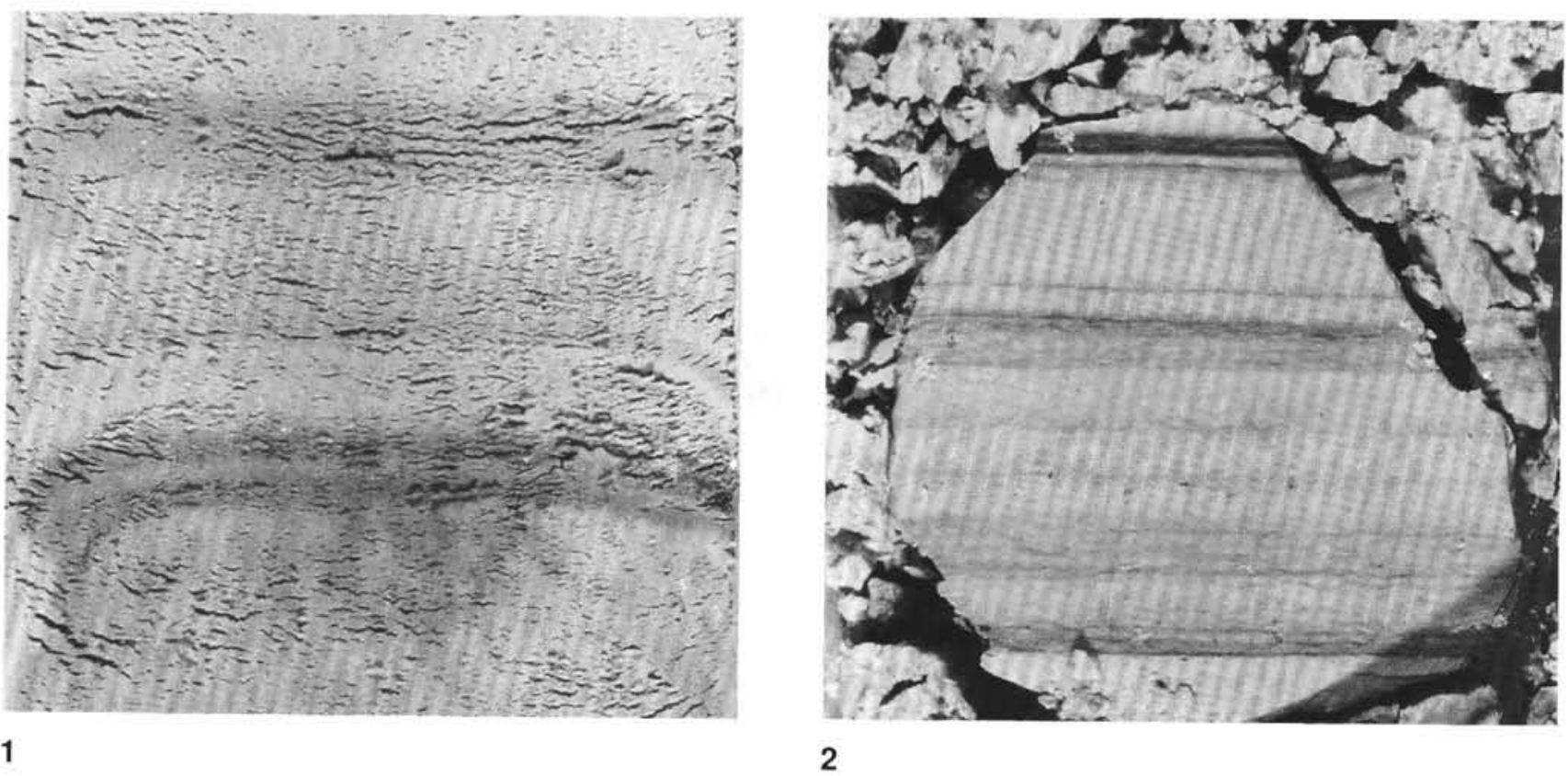

1

$\overline{1 \mathrm{~cm}}$

Plate 1. 1. Diffuse color bands from Section 130-803C-15H-5, 44-50 cm. 2. Narrower color bands from Section 130-803D-48X-4, 37-43 cm. 


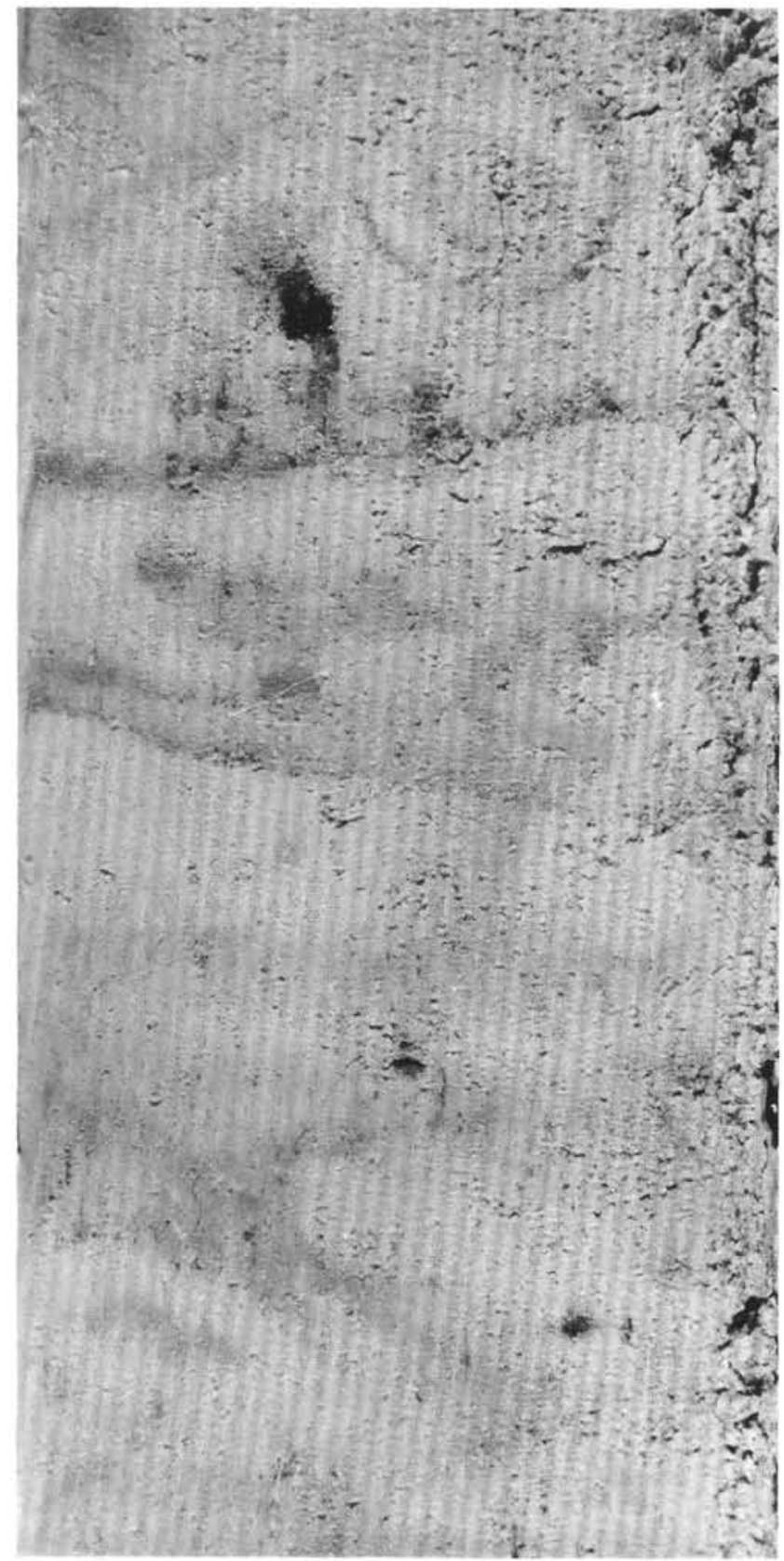

1

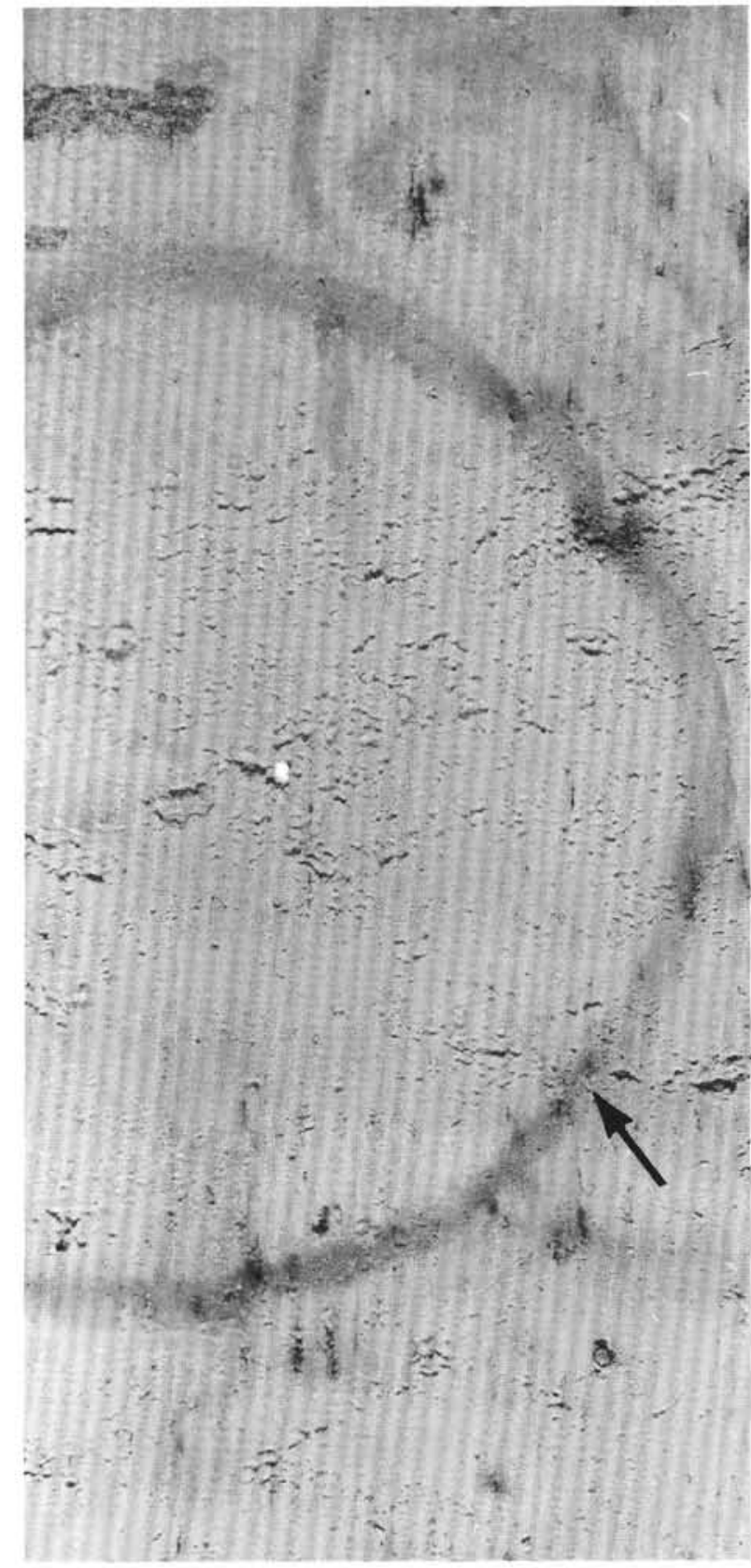

2

$1 \mathrm{~cm}$

Plate 2. 1. Bioturbated ooze from Section 130-806B-20H-7, 10-23 cm, where color bands cross burrows. 2. Purple halo in ooze from Section 130-806B-18H-6, 6-19 cm. At the rim of the halo (arrow), a color band changes color from green inside the halo to purple outside the halo. 


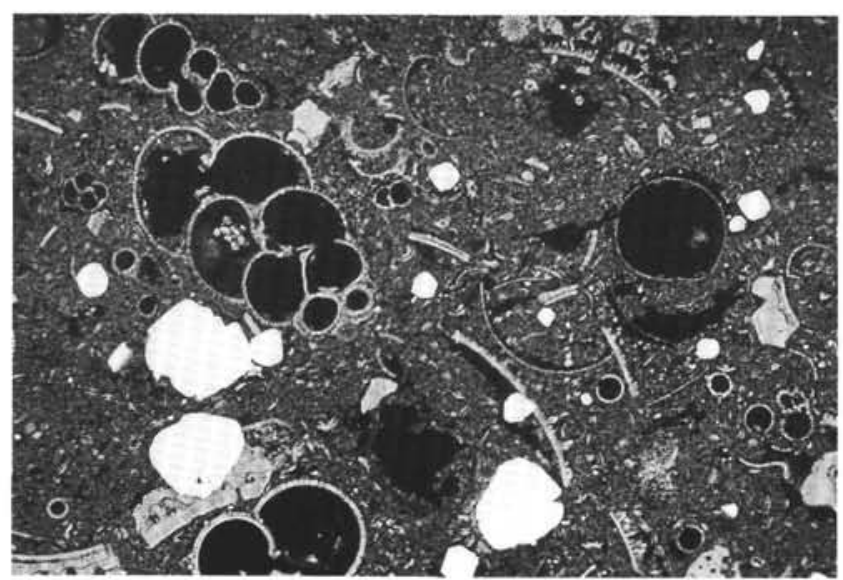

1

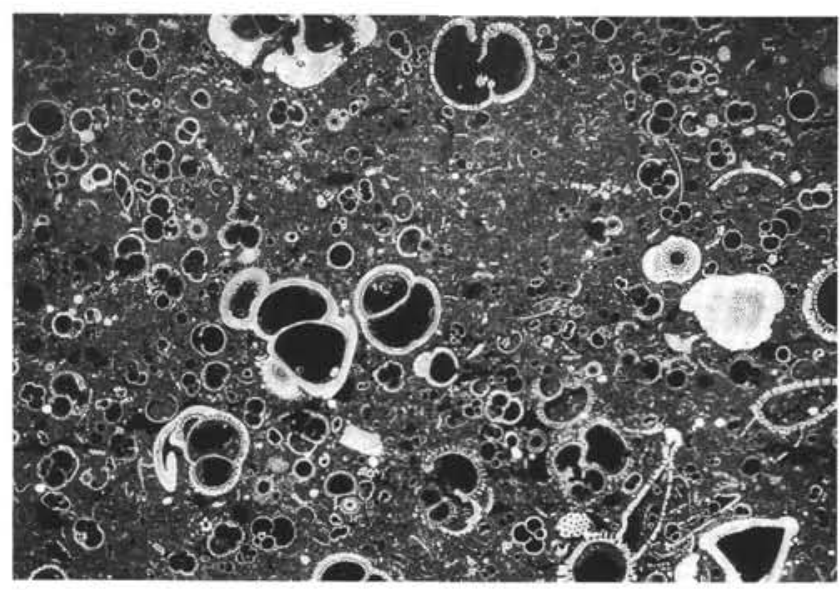

3

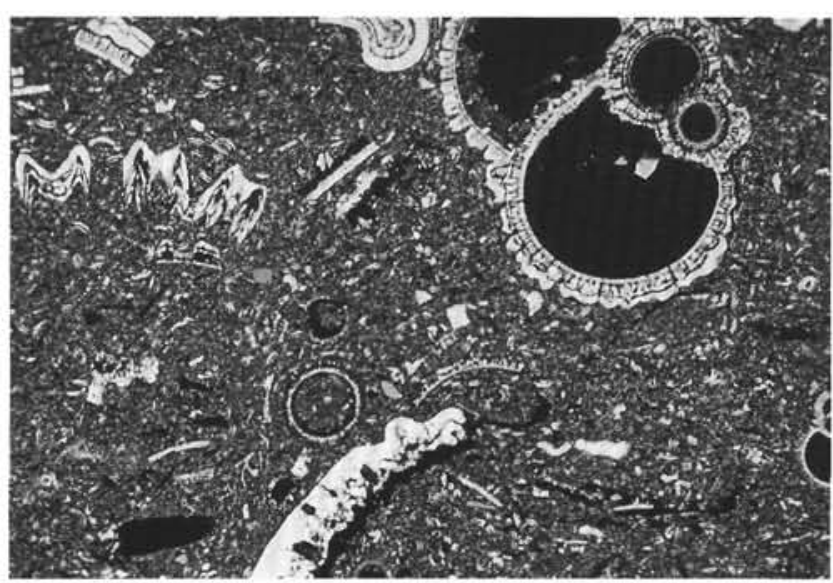

2

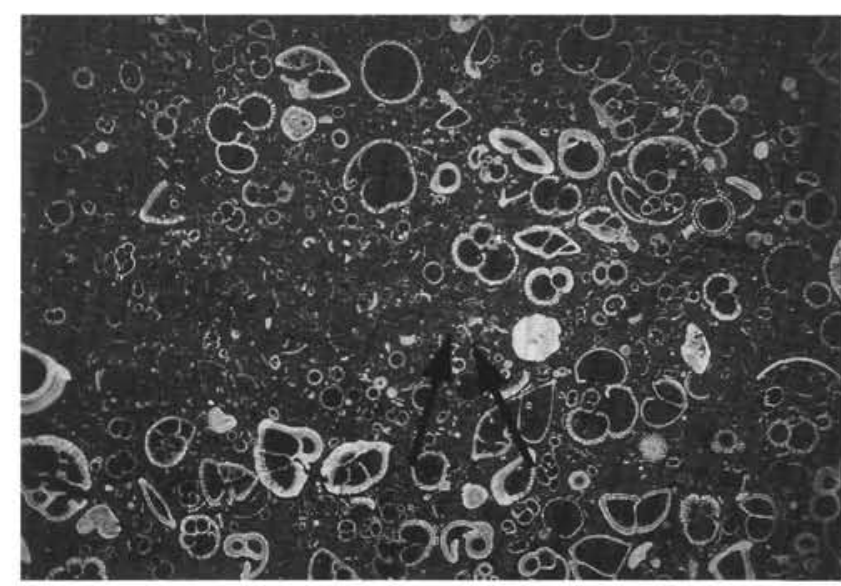

A

B

$1 \mathrm{~mm}$

Plate 3. Backscatter electron micrographs. 1. Section 130-807B-4H-6, 122-124 cm. Purple color band. Authigenic pyrite crystals are scattered in the matrix. 2. Section 130-807B-5H-1, 92-94 cm. Green band. No obvious reason for the green color is seen. 3. Section 130-807B-4H-6, 119-121 cm. White matrix. 4. Section 130-807B-2H-5, 30-32 cm. Green band. The locations of Grains "A" and "B" (Plates 4 and 5, respectively) are indicated by arrows. 


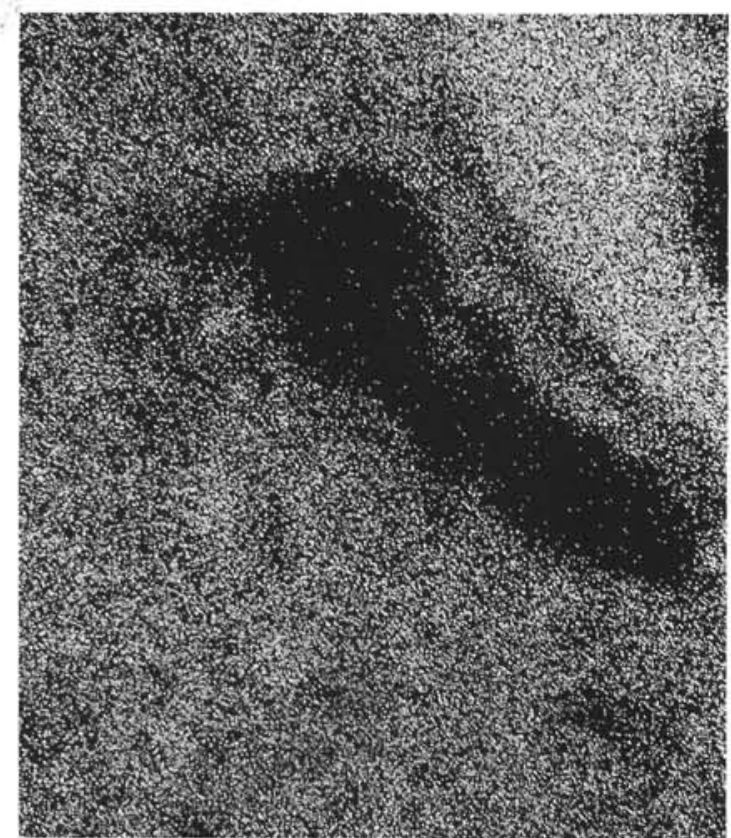

1

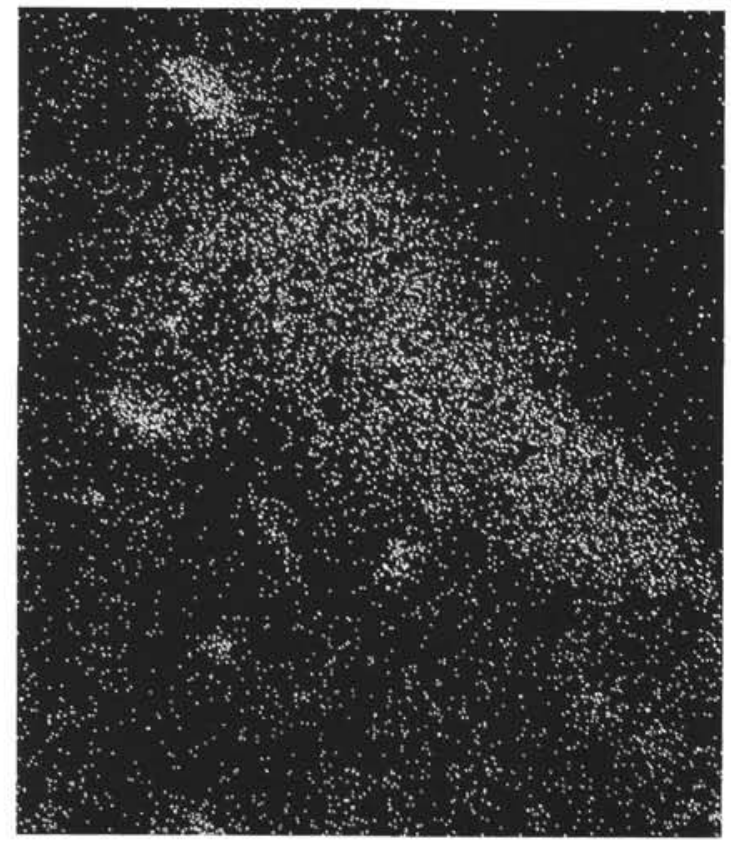

3

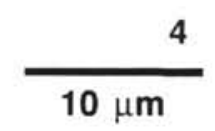

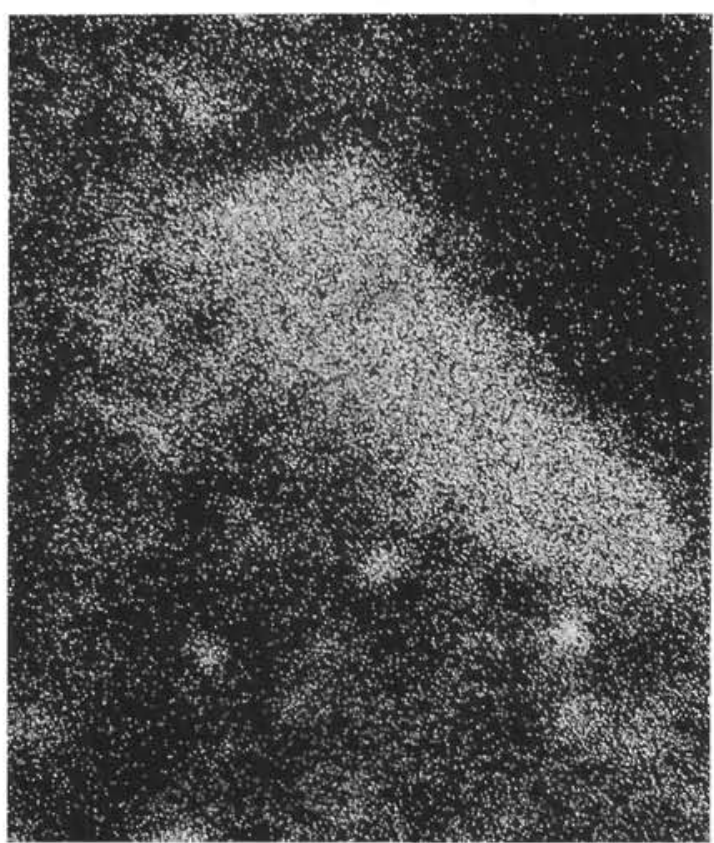

2

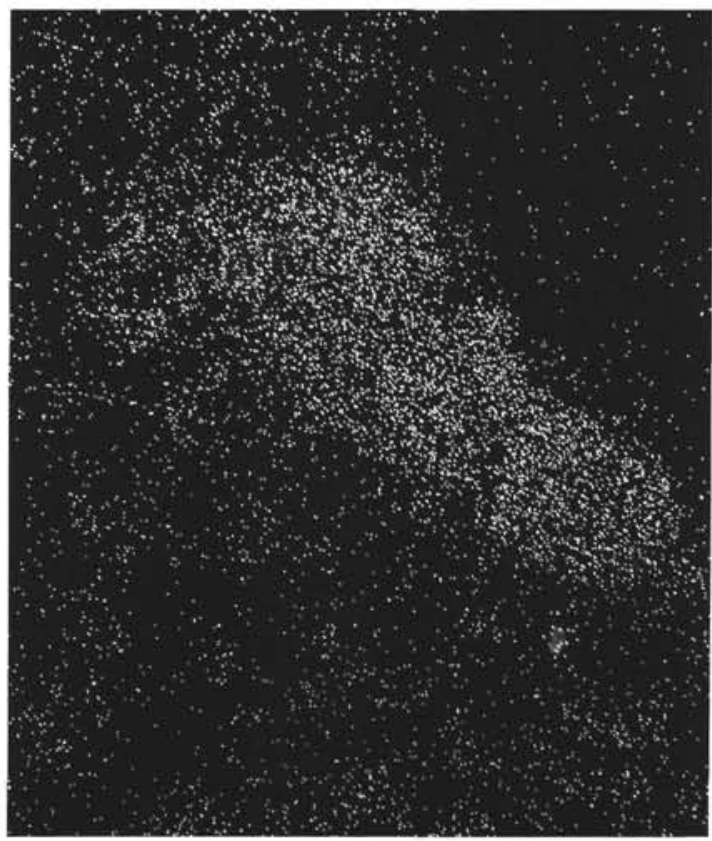

4 


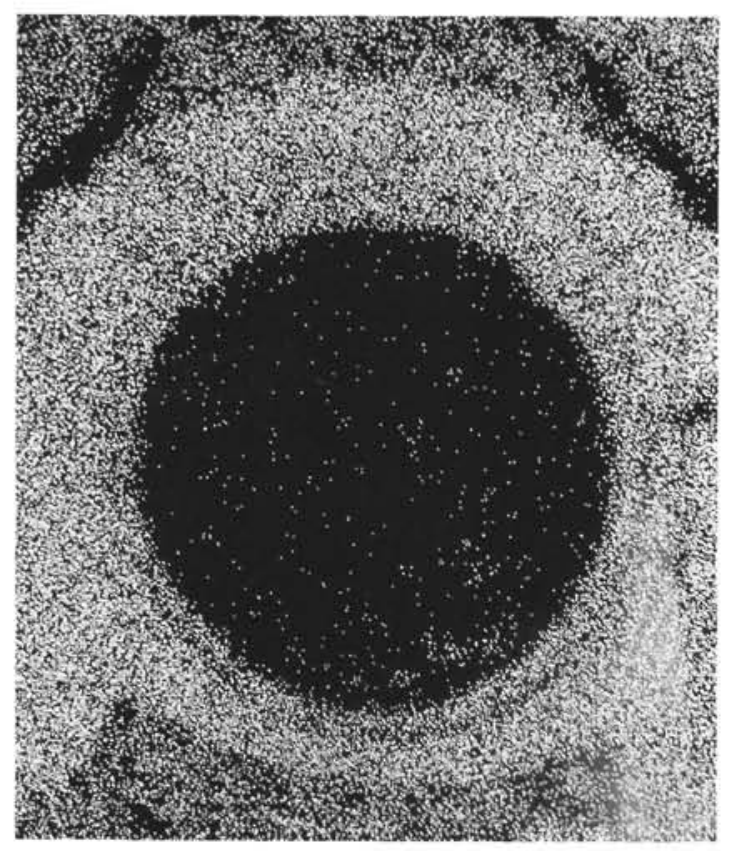

1

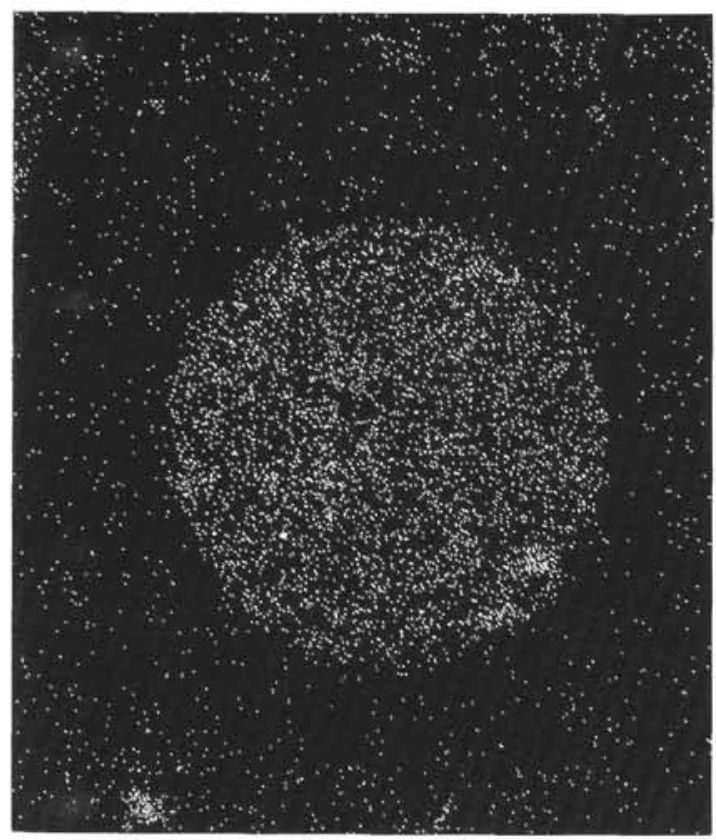

3

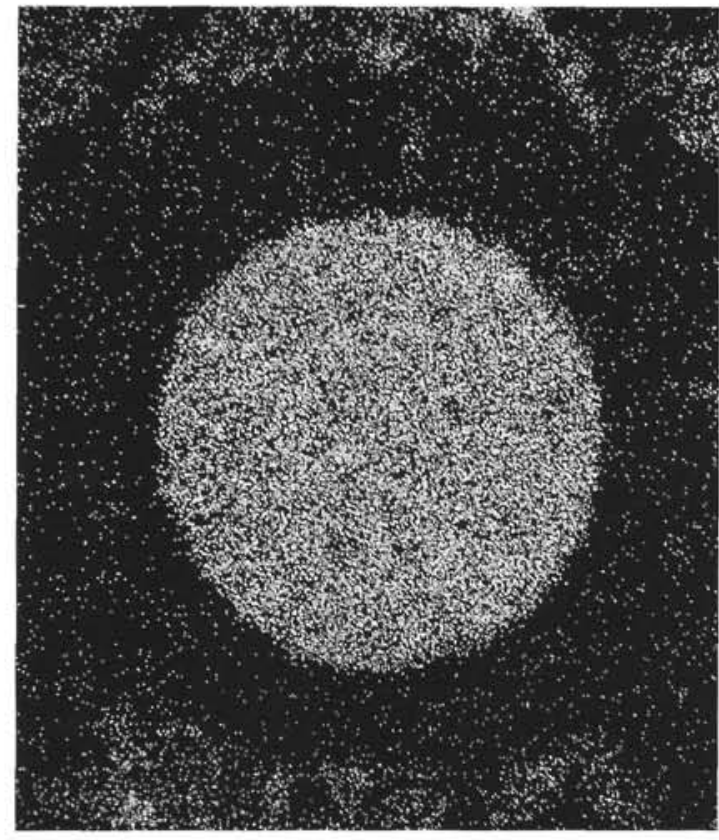

2

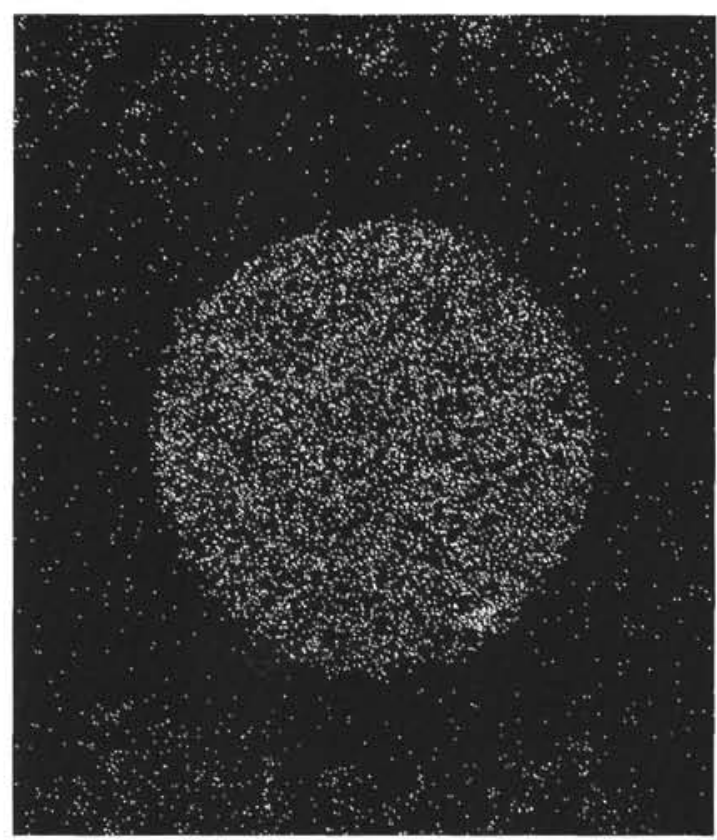

4

$10 \mu \mathrm{m}$

Plate 5. Microprobe dot pictures of Grain "B" (refer to Plate 3). 1. Ca. 2. Si. 3. Al. 4. Fe. 